\title{
Therapeutic Use of Metformin in Prediabetes and Diabetes Prevention
}

\author{
Ulrike Hostalek $^{1} \cdot$ Mike Gwilt $^{2} \cdot$ Steven Hildemann $^{1,3}$
}

Published online: 10 June 2015

(C) The Author(s) 2015. This article is published with open access at Springerlink.com

\begin{abstract}
People with elevated, non-diabetic, levels of blood glucose are at risk of progressing to clinical type 2 diabetes and are commonly termed 'prediabetic'. The term prediabetes usually refers to high-normal fasting plasma glucose (impaired fasting glucose) and/or plasma glucose $2 \mathrm{~h}$ following a $75 \mathrm{~g}$ oral glucose tolerance test (impaired glucose tolerance). Current US guidelines consider highnormal $\mathrm{HbA}_{1 \mathrm{c}}$ to also represent a prediabetic state. Individuals with prediabetic levels of dysglycaemia are already at elevated risk of damage to the microvasculature and macrovasculature, resembling the long-term complications of diabetes. Halting or reversing the progressive decline in insulin sensitivity and $\beta$-cell function holds the key to achieving prevention of type 2 diabetes in at-risk subjects. Lifestyle interventions aimed at inducing weight loss, pharmacologic treatments (metformin, thiazolidinediones, acarbose, basal insulin and drugs for weight loss) and bariatric surgery have all been shown to reduce the risk of progression to type 2 diabetes in prediabetic subjects. However, lifestyle interventions are difficult for patients to maintain and the weight loss achieved tends to be regained over time. Metformin enhances the action of insulin in liver and skeletal muscle, and its efficacy for delaying or preventing the onset of diabetes has been proven in large, well-designed, randomised trials, such as the Diabetes Prevention Program and other studies. Decades of clinical
\end{abstract}

Mike Gwilt

mike.gwilt@lineone.net

Merck KGaA, Darmstadt, Germany

2 GT Communications, 4 Armoury Gardens, Shrewsbury SY2 6PH, UK

3 Universitäts-Herzzentrum Freiburg-Bad Krozingen, Bad Krozingen, Germany use have demonstrated that metformin is generally welltolerated and safe. We have reviewed in detail the evidence base supporting the therapeutic use of metformin for diabetes prevention.

\section{Key Points}

A high prevalence of prediabetes is fuelling the evolving global diabetes pandemic, and optimisation of management of prediabetes is an urgent global clinical priority.

A broad evidence base from clinical trials and previous clinical experience support the efficacy and safety profiles of metformin for diabetes prevention, and highlight subjects in which metformin will be most effective.

Current evidence supports a role for metformin in diabetes prevention, given in addition to lifestyle intervention, in people with prediabetes.

\section{Introduction}

It is well accepted that type 2 diabetes is strongly linked with high morbidity and mortality rates [1]. The markedly increased prevalence of diabetes in recent decades places a severe burden on healthcare systems worldwide $[2,3]$. The diagnosis of diabetes is made according to the level of glycated haemoglobin (HbA1c) or plasma glucose. However, much recent clinical research has focussed on the 
prognostic importance of elevations in fasting and/or postprandial plasma glucose that do not reach the diagnostic cutoff values that would precipitate a diagnosis of type 2 diabetes [4]. These non-diabetic levels of hyperglycaemia are strongly predictive of a high risk of developing type 2 diabetes and have been widely termed 'prediabetic dysglycaemia' or 'prediabetes' [4].

A number of studies, described below, have explored the potential of improvements in lifestyle and/or pharmacologic interventions to prevent or delay the onset of clinical type 2 diabetes in prediabetic subjects, and metformin has been particularly well studied in this regard [5]. The purpose of this review was to summarise the evidence base for the use of metformin in patients with prediabetes.

\section{Search Strategy}

Information in the literature on metformin was identified using a search of PubMed for articles published in English, conducted using the following search string: metformin [ti] AND ("impaired glucose tolerance" OR "impaired fasting glucose" OR "pre-diabet*” OR prediabet* OR “diabetes prevention" OR "prevention of diabetes").

The bibliographies of articles and co-authors' literature collections were also sources of additional references.

\section{Characteristics of Prediabetes}

\subsection{Pathophysiology and Diagnosis of Prediabetes}

The defects in glucose metabolism that underlie type 2 diabetes begin many years before the diagnosis of diabetes is made $[6,7]$. The development of insulin resistance, in which the action of insulin on glucose metabolism is blunted, occurs early in the pathogenesis of dysglycaemia. Increased secretion of insulin initially compensates for the presence of insulin resistance; however, a simultaneous and progressive loss of $\beta$-cell mass and $\beta$-cell function limits the ability of the pancreas to maintain euglycaemia by increasing insulin secretion [8].
The early manifestations of prediabetic dysglycaemia represent one or both of [9]:

- impaired glucose tolerance (IGT), in which postprandial glucose control is impaired but fasting plasma glucose (FPG) is normal;

- impaired fasting glucose (IFG), in which a chronic elevation of FPG occurs in the absence of a deterioration in postprandial glucose control.

Table 1 shows the usually accepted diagnostic criteria for the diagnosis of prediabetes based on measurements of glycaemia [4, 8-10]. A simple blood test is sufficient to diagnose IFG, while a $75 \mathrm{~g}$ oral glucose tolerance test (OGTT) is required for the diagnosis of IGT. The originally used cutoff level for IFG $(110 \mathrm{mg} / \mathrm{dL}$ [6.1 mmol/L]) was reduced to that shown in Table $1(100 \mathrm{mg} / \mathrm{dL}[5.6 \mathrm{mmol} / \mathrm{L}])$ by an Expert Committee of the American Diabetes Association in 2003, in order to equalise the prognostic impact of diagnosis of IFG or IGT, in terms of the future risk of diabetes in a subject with either condition [11]. It should be noted that the World Health Organization (WHO) diagnostic criteria for IFG retains the $110 \mathrm{mg} / \mathrm{dL}(6.1 \mathrm{mmol} / \mathrm{L})$ cutoff value for diagnosing IFG [12].

Diagnostic criteria from the American Diabetes Association also support a diagnosis of prediabetes (but not a specific diagnosis of IFG or IGT) in subjects with elevated, but non-diabetic, levels of $\mathrm{HbA}_{1 \mathrm{c}}$ (5.7-6.4\% [39-46 $\mathrm{mmol} / \mathrm{mol}])$, as this approach identifies a group at high risk of diabetes and other adverse outcomes who may benefit from counselling to identify ways to mitigate these risks [4]. A study from the US National Health and Nutrition Examination Survey (NHANES), published in 2010, found that the use of fasting glucose identified twice as many subjects as having prediabetes compared with the use of HbA1c (28 vs. $13 \%$ ), while only $8 \%$ satisfied both criteria [13]; see below for a fuller discussion of the prevalence of prediabetes. Moreover, HbA1c does not correlate accurately with glucose levels in individuals and may therefore over- or underestimate the current level of glycaemic control [14]. Accordingly, while HbA1c is a convenient measurement for evaluating long-term glycaemic control in diabetes, the impact of its use as a diagnostic criterion for prediabetes will require further study.
Table 1 Classification of impaired glucose tolerance and impaired fasting glucose based on measurements of plasma glucose [4, 8-10]

\begin{tabular}{lcc}
\hline Prediabetic state & FPG $[\mathrm{mg} / \mathrm{dL}(\mathrm{mmol} / \mathrm{L})]$ & 2-h plasma glucose $[\mathrm{mg} / \mathrm{dL}(\mathrm{mmol} / \mathrm{L})]$ \\
\hline NGT & $<100(<5.6)$ & $<140(<7.8)$ \\
IFG & $100-125(5.6-6.9)$ & $140-199(7.8-11.0)$ \\
IGT & $<126(<6.9)$ & $140-199(7.8-11.0)$ \\
Combined IFG/IGT & $100-125(5.6-6.9)$ & $140-199(7.8-11.0)$ \\
\hline
\end{tabular}

$F P G$ fasting plasma glucose, $I F G$ impaired fasting glucose, $I G T$ impaired glucose tolerance, $N G T$ normal glucose tolerance 


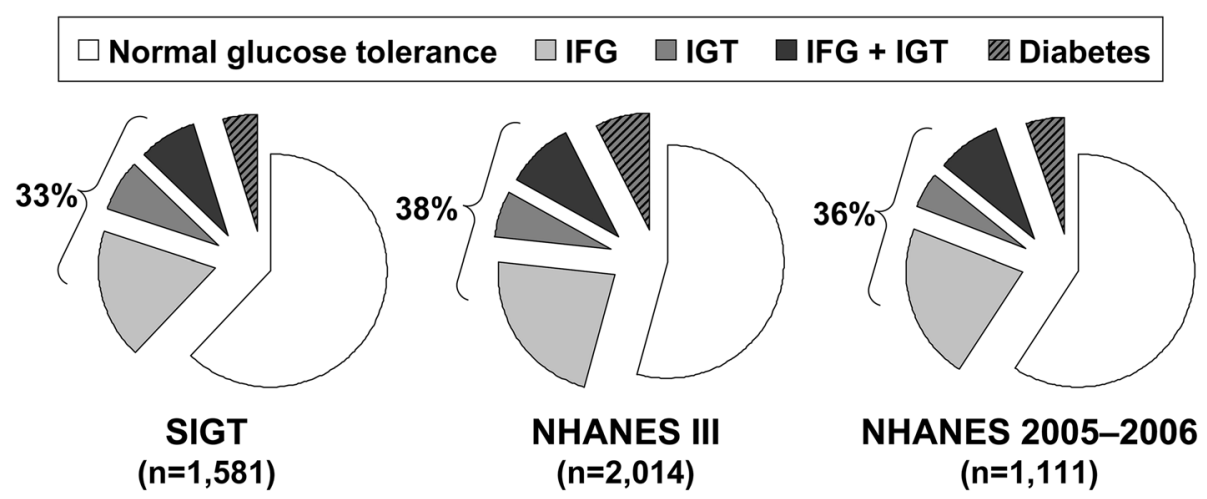

Fig. 1 Prevalence of prediabetes in three cohorts without a prior diagnosis of diabetes in the US, i.e. Screening for Impaired Glucose Tolerance (SIGT), the Third National Health and Nutrition Examination Survey (NHANES III), and the National Health and Nutrition

The loss of glycaemic control as insulin resistance and $\beta$-cell dysfunction develops is insidious, progressive and continuous $[6,7]$. Indeed, clinically normoglycaemic subjects may already have lost at least half of their $\beta$-cell function by the time they progress to IGT, and subjects with IGT and post-OGTT glucose near the cutoff for diagnosis of type 2 diabetes will have lost at least $80 \%$ of their $\beta$-cell function [15].

\subsection{Prevalence of Prediabetes}

The prevalence of both type 2 diabetes and prediabetes has increased rapidly in recent years. A pooled analysis included data from non-diabetic subjects in three population-based observational cohorts in the US [16]: the Screening for Impaired Glucose Tolerance (SIGT) study enrolled 1581 subjects, and other subjects were from the nationally representative NHANES III $(N=2014)$ or NHANES 2005-2006 $(N=1111)$ cohorts. For consistency between cohorts, analyses were restricted to subjects of White/Caucasian or non-Hispanic Black heritage, with lower cutoffs for age $\geq 18$ years for SIGT or NHANES 2005-2006, and $\geq 40$ years for NHANES III (OGTTs were performed for this age group only). Overall, more than $30 \%$ of the population demonstrated one or both forms of prediabetic dysglycaemia (Fig. 1). Similar data are available from the Augsburg (Germany) cohort of the large, international Monitoring Trends and Determinants on Cardiovascular Diseases (MONICA) study, conducted in subjects aged 25-74 years. Among a control group matched for age and gender with a parallel diabetic cohort, $23 \%$ had IGT and $36 \%$ had IFG [17]. According to the International Diabetes Federation, $8 \%$ of the world's population, comprising approximately 470 million individuals, will have IGT by the year 2035 [18].
Examination Survey 2005-2006 (NHANES 2005-2006). Adapted from data presented by Rhee et al. [16]. IFG impaired fasting glucose, IGT impaired glucose tolerance

\subsection{Prediabetes and Adverse Clinical Outcomes}

The Diabetes Prevention Program (DPP), which recruited a population of subjects at elevated risk of diabetes due to IGT plus high-normal FPG, demonstrated that approximately $10 \%$ of subjects progressed to clinical diabetes each year over an average of 2.8 years of follow-up in the study [19]. In general, some $70 \%$ of individuals with IFG and/or IGT can expect to go on to develop clinical type 2 diabetes at some time in the future [8]. People diagnosed with combined IFG and IGT are at increased risk of developing diabetes compared with individuals with only one of these conditions. For example, a pooled analysis of two diabetes prevention studies in India showed that the 3-year incidence of type 2 diabetes in subjects with both IGT and IFG was $56 \%$ compared with $34 \%$ for subjects with isolated IGT [20]. Conversely, only $18 \%$ of subjects with combined IFG and IGT at baseline reverted to normal glucose tolerance compared with $32 \%$ with isolated IGT [20].

Even modest, long-term elevations of plasma glucose, consistent with those associated with IGT or IFG have been associated with damage to the vasculature [21-26]. Retinopathy was diagnosed in $7.9 \%$ of subjects in the DPP who did not progress to type 2 diabetes (compared with $12.6 \%$ of those who did) [27]. In the German control cohort from the MONICA study described above, polyneuropathy was already present in $13 \%$ of subjects with IGT and $11 \%$ with IFG compared with $28 \%$ for subjects with a diagnosis of diabetes and $7 \%$ with normal glucose tolerance [17].

Prediabetic dysglycaemia also increases the risk of adverse cardiovascular events (such as myocardial infarction, stroke or cardiovascular death; see reviews elsewhere $[28,29])$. In addition, as an insulin resistant state, prediabetes frequently coexists with other cardiovascular risk factors associated with the metabolic syndrome, such as 
elevated blood pressure and dyslipidaemia [30]. Insulin resistance, which appears early in the pathogenesis of dysglycaemia and is likely to be present in most prediabetic subjects, is itself a powerful prognostic indicator for an increased risk of diabetes or cardiovascular disease [6-8].

Intervention in prediabetes is known to prevent or delay the onset of diabetes, a state known to be associated with markedly elevated cardiovascular risk [31]. The appearance in the circulation of the cardiac-specific isozyme of troponin is indicative of damage to the myocardium, and is associated with an adverse long-term prognosis [32]. A recent study has demonstrated elevated circulating cardiac troponin $\mathrm{T}$ in $11 \%$ of diabetic subjects, $6 \%$ of subjects with IGT and $4 \%$ of subjects who remained normoglycaemic over 6 years of follow-up [33]. Accordingly, the presence of prediabetes may be associated with subclinical damage to the myocardium.

It is clear that the increased risk of adverse cardiovascular outcomes associated with type 2 diabetes does not begin at the diagnostic cutoff for plasma glucose (or HbA1c) at which the condition is diagnosed. Rather, there appears to be a continuum of increased microvascular and macrovasular risk that extends to levels of glycaemia well below these cutoffs. While it seems reasonable to hypothesise that correction of prediabetic dysglycaemia might also reduce the future risk of adverse cardiovascular outcomes, further evidence from clinical trials is needed to demonstrate improved long-term outcomes in this setting [31].

\subsection{Principles of Management of Prediabetes}

Prediabetes (IGT and IFG) and clinically established type 2 diabetes are each characterised by insulin resistance and $\beta$-cell dysfunction, and represent a continuum of increasing severity of dysglycaemia, as described above. Accordingly, the overall principles of managing diabetes and prediabetes are similar [4]. People at risk of diabetes, particularly those who are overweight or obese, or women with a history of gestational diabetes, should be tested for the presence of prediabetes or diabetes alongside other cardiovascular risk factors.
Lifestyle intervention remains the cornerstone of care for individuals with prediabetes or diabetes, based on an improved diet and regular moderate physical exercise with the aim of achieving weight loss in overweight or obese subjects (Table 2) [4, 34]. Pharmacologic therapy with interventions used to promote weight loss (e.g. orlistat or bariatric surgery) or with drugs usually used for the management of type 2 diabetes (metformin, thiazolidinediones, $\alpha$-glucosidase inhibitors or basal insulin) have also been shown to effectively delay or prevent the conversion of prediabetes to diabetes (described below).

Currently, metformin is the only pharmacologic agent recommended for the prevention or delay of type 2 diabetes in at-risk subjects due to its effectiveness as demonstrated in well-designed trials (see below), its generally good tolerability (aside from the well-understood gastrointestinal side effects associated with this agent) and its low cost [4, 34]. At present, metformin has no formal indication for this purpose in most countries (Turkey, Poland, and The Philippines are exceptions), although such an indication may become established in many countries in the future. The remainder of this review will focus in detail on the therapeutic profile of metformin for the management of prediabetes and other insulin-resistant states that predispose to the subsequent development of type 2 diabetes.

\section{Overview of the Pharmacologic Properties of Metformin}

\subsection{Principal Therapeutic Sites of Action of Metformin}

A brief summary of the pharmacologic mechanism and clinical actions of metformin is provided in this review as these are relevant to its therapeutic effects on prediabetic subjects. Preventing or reversing the progressive insulin resistance and/or $\beta$-cell dysfunction associated with dysglycaemia holds the key to preventing or delaying the conversion of prediabetes to clinical type 2 diabetes.

Table 2 Overview of lifestyle recommendations for prediabetes from the US and Europe

\begin{tabular}{|c|c|c|}
\hline & US (ADA) [4] & Europe (European multidisciplinary consortium) [32] \\
\hline $\begin{array}{l}\text { Weight } \\
\text { loss }\end{array}$ & $7 \%$ of initial weight ${ }^{a}$ & $5-7 \%$ of initial weight \\
\hline Exercise & $150 \mathrm{~min} /$ week of moderate exercise ${ }^{a}$ & $30 \mathrm{~min} /$ day of moderate exercise \\
\hline Diet & $\begin{array}{l}\text { No specific recommendations, refer to intensive behavioural } \\
\text { management to achieve the } 7 \% \text { weight loss goal }\end{array}$ & $\begin{array}{l}\geq 15 \mathrm{~g} \text { fibre per } 1000 \mathrm{kcal}, \leq 35 \% \text { of total energy as fat, }<10 \% \\
\text { of total energy as saturated fat or trans fat }\end{array}$ \\
\hline
\end{tabular}


Metformin acts primarily by enhancing the action of insulin in the liver to reduce the rate of hepatic glucose production [35]. Improvements in insulin action in skeletal muscle also contribute to the therapeutic actions of metformin, mainly resulting in increased non-oxidative glucose disposal [36]. Together, these actions reduce blood glucose in the setting of hyperglycaemia, with very little potential for inducing hypoglycaemia [37].

An increase in anaerobic metabolism in the intestinal wall is also probably a clinically significant antihyperglycaemic mechanism of metformin [38, 39]. In addition, metformin has been shown to increase circulating levels of glucagon-like peptide-1 (GLP-1) by increasing the secretion of GLP-1 itself and/or by decreasing the activity of dipeptidyl peptidase-4 (DPP4), the enzyme principally responsible for inactivating GLP-1 in the tissues and circulation [40-42]. Metformin may also induce upregulation of the expression of GLP-1 receptors on the surface of pancreatic $\beta$-cells [41]. As GLP-1 enhances glucose-dependent insulin release from the pancreas, this mechanism may provide modest support to the function of the $\beta$ cell $[40,43]$. An effect of metformin on the gut microbiome has also been postulated [44].

\subsection{Molecular Mechanisms for the Antihyperglycaemic Actions of Metformin}

Mechanistically, metformin appears to inhibit mitochondrial respiration at the level of respiratory chain complex I [45]. The resulting shift in cellular energy balance increases the activity of AMP kinase, which promotes the action of insulin and reduces hepatic gluconeogenesis [45]. An increase in circulating cyclic adenosine monophosphate (cAMP) also opposes the hyperglycaemic action of glucagon $[45,46]$. Other studies have shown that metformin enhances the action of DPP4 inhibitors by either reducing the activity of DPP4 or enhancing secretion of GLP-1 [47, 48]. Metformin relies on transport into cells via the organic cation transporter-1 (OCT1) for its clinical action, and polymorphisms of this transporter influence the efficacy of metformin in type 2 diabetes [49, 50]. The relevance of this mechanism for diabetes prevention has yet to be determined and further research is required.

\subsection{Cardiovascular Actions of Metformin}

In the UK Prospective Diabetes Study (UKPDS), metformin was the first antidiabetic drug shown to improve cardiovascular prognosis [51]; clinically significant reductions in the risk of a range of adverse outcomes were observed, relative to the standard diet-based treatment of the time, including all-cause mortality, diabetes-related death and myocardial infarction, which were greater than those expected from improved blood glucose control per se. Long-term epidemiologic follow-up of this trial beyond the randomised phase demonstrated 'legacy benefits', in which cardiovascular benefits persisted in patients previously randomised to metformin despite the cessation of randomised treatment and rapid equalisation of mean $\mathrm{HbA}_{1 \mathrm{c}}$ between patients previously in the metformin and control arms of the study [52]. A second trial in insulintreated patients also demonstrated improved cardiovascular outcomes in patients randomised to metformin relative to placebo [53]. Improved cardiovascular outcomes with metformin is included in the European labelling of this drug. The forthcoming Glucose Lowering In Non-diabetic hyperglycaemia Trial (GLINT) trial is expected to definitively demonstrate the extent to which metformin protects the vasculature in a prediabetic population at high risk of adverse cardiovascular events [54].

Improvements in glycaemia during treatment with metformin were insufficient to explain the improved cardiovascular outcomes observed in the UKPDS [52]. A recent uncontrolled study in 390 insulin-treated type 2 diabetes patients showed that long-term treatment with metformin (average 4.3 years) reduced levels of a range of circulating markers of endothelial dysfunction; these observations were consistent with a protective effect on the vasculature, as endothelial dysfunction is an early marker of atherosclerosis [55]. Numerous other mechanisms have been proposed to explain the protective effect of metformin on the vasculature in the UKPDS, including improved haemostasis (reduced potential for atherothrombotic disease), reduced vascular inflammation, amelioration of oxidative stress, inhibition of the formation of advanced glycation end-products, improved function of the microcirculation and modification of the cellular processes that occur during atherogenesis [56].

\subsection{Safety and Tolerability}

The principal side effects of metformin occur in the gastrointestinal tract (mostly diarrhoea); these can be minimised by starting metformin at a low dose and increasing the dose cautiously and infrequently cause treatment discontinuation [57]. Prolonged-release formulations of metformin are available, which appear to improve gastrointestinal tolerability compared with the immediaterelease formulation [58]. Biguanide antidiabetic agents have long been associated with an increased risk of lactic acidosis but it is now clear that the risk of lactic acidosis with metformin is extremely low when this agent is prescribed correctly $[59,60]$. Contraindications to metformin intended to reduce the risk of lactic acidosis, as described in its labelling, generally reflect cardiovascular morbidity 
and renal dysfunction that might provoke accumulation of metformin in the body-these conditions are less likely to be prevalent in a prediabetic population compared with a population with established type 2 diabetes at higher risk of long-term complications of the disease.

Treatment with metformin has also been associated with clinically significant vitamin $\mathrm{B}_{12}$ deficiency in some patients, where neuropathy arising from low levels of $\mathrm{B}_{12}$ may mimic diabetic neuropathy [61]. A 4.3-year study demonstrated an increase in the risk of clinical $\mathrm{B}_{12}$ deficiency $(<150 \mathrm{pmol} / \mathrm{L})$ of $7 \%$, with an average reduction in $\mathrm{B}_{12}$ levels of $19 \%$, each compared with placebo [62]. A meta-analysis of 29 studies that included a total of 8089 patients found that metformin increased the risk of $B_{12}$ deficiency, with an odds ratio (OR) of 2.45 versus comparators [63]. Monitoring $B_{12}$ levels, with supplementation where necessary, may be useful in all subjects receiving long-term treatment with metformin.

\section{Principal Diabetes Prevention Trials with Metformin}

\subsection{Overview}

The principal features and main results of major trials that evaluated metformin for diabetes prevention are shown in Table 3 [19, 64-69]. Significant reductions in the risk of progressing from prediabetes (principally IGT) to type 2 diabetes in subjects treated with metformin were observed in populations in:

- The US, in the DPP [19]

- India, in the Indian DPP (IDDP) [65]

- China [66, 68]

- Canada, in the CAnadian Normoglycemia Outcomes Evaluation (CANOE) [64]

- Pakistan [67].

These trials will be described in greater detail in the following sections. Details of trials that did not evaluate metformin are also shown in Table 3, for comparison [7078]. Lifestyle intervention was consistently effective in reducing the risk of diabetes and should be recommended for all subjects at risk of diabetes or cardiovascular disease, irrespective of other therapies prescribed. It is also clear that thiazolidinediones, $\alpha$-glucosidase inhibitors and weight-reducing interventions also have the potential to prevent or delay the onset of diabetes in prediabetic subjects. A post hoc analysis of the STOP-NIDDM (Study to Prevent NonInsulin-Dependent Diabetes Mellitus) trial [72] suggested a reduced incidence of hypertension and cardiovascular disease for acarbose versus placebo in subjects with IGT, although the number of events was low [73].

\subsection{The Diabetes Prevention Program (DPP)}

The effects of metformin on diabetes outcomes in the DPP, and also on cardiometabolic endpoints relevant to diabetes prevention, are discussed in detail here. Health economic analyses are discussed separately in a later section, alongside comparable analyses from other trials.

\subsubsection{The Randomised Phase of the DPP}

A total of 3234 subjects were randomly assigned to a multifactorial intensive lifestyle intervention, metformin plus standard lifestyle advice or placebo plus standard lifestyle advice in the DPP [19]. It is unfortunate that metformin plus intensive lifestyle intervention was not studied in the DPP as this combination might be expected to provide additive protection from conversion to type 2 diabetes in a prediabetic population (although no such additive benefits were observed in the IDDP; see below). Participants in the DPP were followed up for long-term clinical outcomes in the DPP Outcomes Study (DPPOS), which is described separately below [69].

The study design involved recruitment of a high-risk population for diabetes, with approximately $45 \%$ of subjects being from ethnic groups with a higher risk of developing type 2 diabetes compared with Caucasians, including African Americans (20\% of the overall population), Hispanic subjects (16\%), Native Americans (5\%) and Asian Americans (4\%) [79, 80]. Inclusion criteria relating to FPG $(5.3-6.9 \mathrm{mmol} / \mathrm{L}$ [95-119 mg/dL] for all, with the exception of Native American subjects) and body mass index (BMI; $\geq 22 \mathrm{~kg} / \mathrm{m}^{2}$ for Asian Americans and $\geq 24 \mathrm{~kg} / \mathrm{m}^{2}$ for all others) also ensured an enhanced risk of developing type 2 diabetes among the study population.

Standard lifestyle advice consisted of an annual meeting with a healthcare professional, and written material on a healthy lifestyle. The intensive lifestyle group received face-to-face instruction and advice on maintaining a healthy lifestyle (individually and in groups). Subjects in this group were given a weight loss goal of $\geq 7 \%$, with a lowcalorie/low-fat diet, and $\geq 150 \mathrm{~min} /$ week of moderate exercise. Metformin was administered as one $850 \mathrm{mg}$ tablet, titrated to $850 \mathrm{mg}$ twice daily after 1 month depending on tolerability ( $84 \%$ of subjects were receiving twice-daily treatment by study end).

The study was terminated after 2.8 years ( 1 year early) as routine data monitoring suggested that the primary endpoint (incidence of new diabetes) had been met. Reductions in body weight were maximal in the intensive lifestyle intervention and metformin groups at 0.5-1 year, and then tended to reverse (Fig. 2). Mean weight loss at 4 years was $5.6 \mathrm{~kg}$ for the intensive lifestyle intervention, 
Table 3 Overview of principal diabetes prevention trials with and without evaluation of metformin

\begin{tabular}{|c|c|c|c|c|c|c|}
\hline Trial & Design & Subjects & $\begin{array}{l}N ; \\
\text { duration } \\
\text { (years) }\end{array}$ & Control group & Active treatments & $\begin{array}{l}\% \text { change in } \\
\text { diabetes risk }\end{array}$ \\
\hline \multicolumn{7}{|c|}{ Principal diabetes prevention trials that evaluated metformin } \\
\hline DPP (US) [19] & $\mathrm{RCT}$ & $\begin{array}{l}\text { IGT and high-- } \\
\text { normal glucose }\end{array}$ & $3234 ; 3$ & $\begin{array}{l}\text { Placebo plus standard } \\
\text { lifestyle advice }\end{array}$ & $\begin{array}{l}\text { Metformin plus standard } \\
\text { lifestyle advice } \\
\text { Intensive lifestyle intervention }\end{array}$ & $\begin{array}{l}-31 \\
-58\end{array}$ \\
\hline $\begin{array}{l}\text { DPP Outcome Study } \\
\text { (US) [69] }\end{array}$ & $\mathrm{O}$ & $\begin{array}{l}\text { Epidemiological } \\
\text { follow-up to DPP }\end{array}$ & $2766 ; 5.7$ & $\begin{array}{l}\text { Placebo plus } \\
\text { intensive lifestyle } \\
\text { advice }\end{array}$ & $\begin{array}{l}\text { Metformin } \\
1700 \mathrm{mg} / \text { day }+ \text { intensive } \\
\text { lifestyle advice } \\
\text { Intensive lifestyle advice }\end{array}$ & $\begin{array}{l}-13 \\
+5\end{array}$ \\
\hline IDPP (India) [20, 65] & RCT & IGT & $531 ; 2.5$ & $\begin{array}{l}\text { Standard lifestyle } \\
\text { advice }\end{array}$ & $\begin{array}{l}\text { Metformin plus standard } \\
\text { lifestyle advice } \\
\text { Metformin plus intensive } \\
\text { lifestyle intervention } \\
\text { Intensive lifestyle intervention }\end{array}$ & $\begin{array}{l}-26 \\
-28 \\
-29\end{array}$ \\
\hline $\begin{array}{l}\text { Wenying et al. (China) } \\
\text { [68] }\end{array}$ & NR & IGT & $321 ; 3$ & $\begin{array}{l}\text { Standard lifestyle } \\
\text { advice }\end{array}$ & $\begin{array}{l}\text { Metformin } \\
\text { Acarbose } \\
\text { Intensive lifestyle intervention }\end{array}$ & $\begin{array}{l}-88 \\
-87 \\
-43\end{array}$ \\
\hline $\mathrm{Li}$ et al. (China) [66] & $\mathrm{RCT}$ & IGT & $70 ; 1$ & Placebo & Metformin & $-66^{\mathrm{a}}$ \\
\hline $\begin{array}{l}\text { Iqbal Hydrie et al. } \\
\text { (Pakistan) [67] }\end{array}$ & $\mathrm{RCT}$ & IGT & $317 ; 1.5$ & $\begin{array}{l}\text { Standard lifestyle } \\
\text { advice }\end{array}$ & $\begin{array}{l}\text { Metformin } \\
\text { Intensive lifestyle intervention }\end{array}$ & $\begin{array}{l}-76.5 \\
-71\end{array}$ \\
\hline $\begin{array}{l}\text { CANOE (Canada) } \\
\text { [64] }\end{array}$ & $\mathrm{RCT}$ & IGT & $207 ; 3.9$ & Placebo & $\begin{array}{l}\text { Metformin } 500 \mathrm{mg} \text { plus } \\
\text { rosiglitazone } 2 \mathrm{mg} \text { twice } \\
\text { daily }\end{array}$ & -66 \\
\hline \multicolumn{7}{|c|}{ Principal diabetes prevention trials that did not evaluate metformin } \\
\hline $\begin{array}{l}\text { Diabetes Prevention } \\
\text { Study (Finland) [70] }\end{array}$ & $\mathrm{RCT}$ & IGT & $522 ; 3.2$ & $\begin{array}{l}\text { Standard lifestyle } \\
\text { advice }\end{array}$ & $\begin{array}{l}\text { Intensive, multifactorial } \\
\text { lifestyle intervention }\end{array}$ & -58 \\
\hline $\begin{array}{l}\text { Da Qing study (China) } \\
\text { [71] }\end{array}$ & RBS & IGT & $577 ; 6$ & $\begin{array}{l}\text { Standard lifestyle } \\
\text { advice }\end{array}$ & Diet, exercise, or both together & -31 to -46 \\
\hline $\begin{array}{l}\text { STOP-NIDDM } \\
\left(^{\text {International }}{ }^{\mathrm{b}}\right) \\
{[72,73]}\end{array}$ & $\mathrm{RCT}$ & IGT & $1429 ; 3.3$ & Placebo & Acarbose & -25 \\
\hline $\begin{array}{l}\text { XENDOS (Sween) } \\
{[74]}\end{array}$ & $\mathrm{RCT}$ & IGT and obesity & $694 ; 4^{\mathrm{c}}$ & Placebo & Orlistat & -45 \\
\hline $\begin{array}{l}\text { DREAM }(21 \\
\left.\text { countries }^{\mathrm{d}}\right)[75,76]\end{array}$ & $\mathrm{RCT}$ & $\mathrm{IGT} \pm \mathrm{IFG}$ & $5269 ; 3$ & $\begin{array}{l}\text { Placebo } \\
\text { Placebo }\end{array}$ & $\begin{array}{l}\text { Rosiglitazone } \\
\text { Ramipril }\end{array}$ & $\begin{array}{l}-62^{\mathrm{e}} \\
-9^{\mathrm{f}}(\mathrm{NS})\end{array}$ \\
\hline IDPP-2 (India) [77] & $N^{f}$ & IGT & $407 ; 3$ & $\begin{array}{l}\text { Placebo + lifestyle } \\
\text { intervention }\end{array}$ & $\begin{array}{l}\text { Pioglitazone }+ \text { lifestyle } \\
\text { intervention }\end{array}$ & $+8(\mathrm{NS})$ \\
\hline $\begin{array}{l}\text { SOS study (Sweden) } \\
\text { [78] }\end{array}$ & $\mathrm{RCT}$ & $\begin{array}{l}\text { Obese, non- } \\
\text { diabetic }\end{array}$ & $3429 ; 10$ & No surgery ${ }^{\mathrm{g}}$ & Bariatric surgery & -83 \\
\hline
\end{tabular}

All studies employed a randomised design, with the exception of the Wenying study

CANOE low-dose combination therapy with rosiglitazone and metformin to prevent type 2 diabetes mellitus trial, DREAM Diabetes Reduction Assessment with Ramipril and Rosiglitazone Medication, IDDP-2 Indian Diabetes Prevention Programme-2, SOS Swedish Obese Subjects, STOP-NIDDM Study to Prevent Non-Insulin-Dependent Diabetes Mellitus, XENDOS Xenical in the Prevention of Diabetes in Obese Subjects, $N R$ non-randomised, $O$ observational follow-up study, $R B S$ randomised by site, $R C T$ randomised controlled trial, $N S$ not significantly different relative to the control group shown, DPP Diabetes Prevention Programme, IGT impaired glucose tolerance, $I F G$ impaired fasting glucose

${ }^{\text {a }}$ From data presented (diabetes developed in $16 \%$ of the placebo group and $3 \%$ of the metformin group)

b Canada, Germany, Austria, Norway, Denmark, Sweden, Finland, Israel, Spain

c Subjects with IGT (the overall trial population comprised 3305 subjects)

d Argentina, Australia, Brazil, Canada. Chile, Finland, Germany, Hungary, India, Latvia, Mexico, The Netherlands, Norway, Poland, Slovakia, Spain, Sweden, Sweden, Turkey, UK, US

${ }^{\mathrm{e}}$ Rreduction in the risk of the primary outcome (diabetes or death) for rosiglitazone vs. placebo

${ }^{\mathrm{f}}$ Subjects were allocated to groups sequentially

g Subjects from the study cohort were matched to the surgical intervention group using 18 variables 


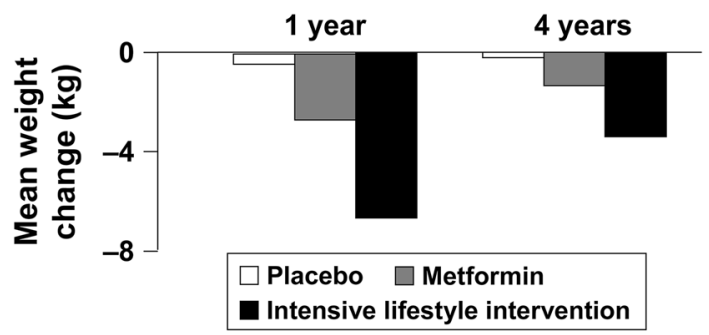

Fig. 2 Mean changes in weight during the randomised phase of the Diabetes Prevention Program. Placebo and metformin were administered in combination with standard lifestyle advice. Adapted from data presented by the Diabetes Prevention Program Research Group [19]

$2.1 \mathrm{~kg}$ for metformin and $0.1 \mathrm{~kg}$ for placebo. Increased physical activity was only seen in the intensive lifestyle intervention group. New-onset diabetes occurred at a rate of 11.0 cases/100 subject-years in the control group (placebo plus standard lifestyle advice) compared with 7.8 cases/100 subject-years in the metformin group and 4.8 cases/100 subject-years in the intensive lifestyle intervention group (corresponding to relative risk reductions of $-31 \%[95 \% \mathrm{CI}-17$ to -43 and $-58 \%$ [95\% CI -48 to $-66]$, respectively). The number needed to treat to prevent one case of incident diabetes was 6.9 for the intensive lifestyle intervention and 13.9 for metformin. The efficacy of metformin approached that of the intensive lifestyle intervention in younger subjects and those with higher BMI or FPG at baseline (Fig. 3). The median delay in diabetes onset was estimated at 11 years for the intensive lifestyle intervention and 3 years for metformin [81].

Lower fasting glucose, weight loss, younger age and higher insulin secretion predicted reversion from IGT to normal glucose tolerance in the DPP [82]. There was a nonsignificant trend for reversion to normal glucose tolerance in the metformin group, which was significant for subjects with both IGT and IFG at baseline.

A total of 1274 subjects randomised to placebo or metformin and without diabetes at study end participated in a washout study, involving an evaluation of glycaemic status after 1-2 weeks off treatment [83]. A lower risk of diabetes on metformin (OR 0.66; $95 \%$ CI 0.54-0.82; $p<0.001$ ) became non-significant after the washout (OR 1.49 ; $95 \%$ CI $0.93-2.38 ; p=0.098)$. Taking the combined rate of conversions to diabetes from the doubleblind and washout phases showed that some of the effect of metformin on the risk of diabetes had persisted (OR $0.75 ; 95 \%$ CI $0.62-0.92 ; p<0.005)$. Neither age nor BMI at baseline influenced these findings. It was calculated that only $26 \%$ of the effect of metformin was a short-lived effect that reversed quickly after withdrawal of study therapy. (a)

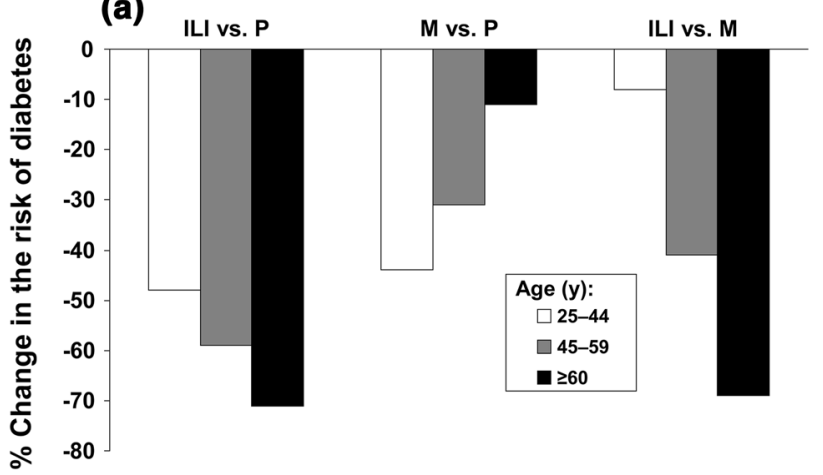

(b)

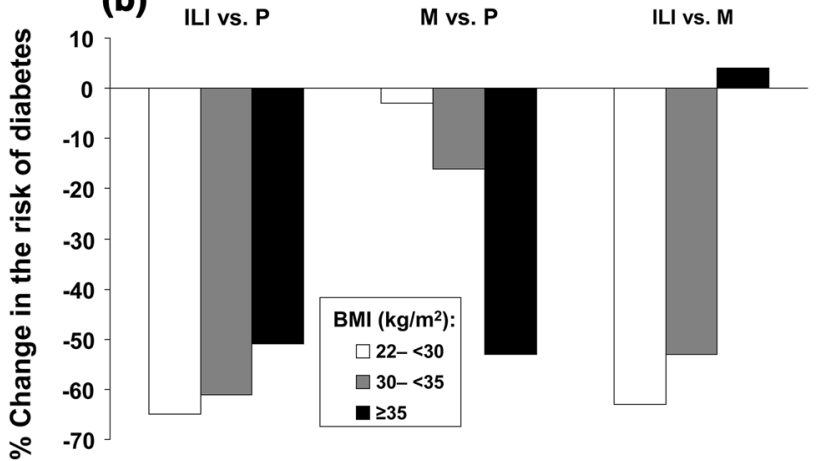

(c)

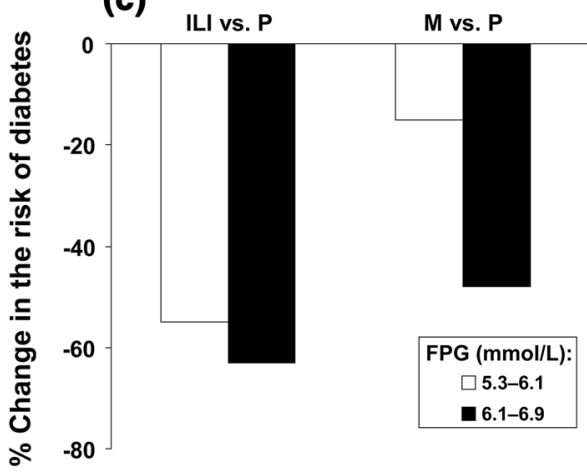

Fig. 3 Effects of treatments in the Diabetes Prevention Program on the risk of diabetes following stratification of the population for age, FPG or BMI at baseline. a Age at baseline; b BMI at baseline; $\mathbf{c}$ FPG at baseline. Comparisons shown are for ILI vs. P, M vs. P, and ILI vs. $M$. In each case, a more strongly negative change in risk signifies greater efficacy of the first named agent. Adapted from data presented by the Diabetes Prevention Program Research Group [19]. FPG fasting plasma glucose, $B M I$ body mass index, $I L I$ intensive lifestyle intervention, $M$ metformin, $P$ placebo

\subsubsection{The DPP Outcomes Study (DPPOS)}

The majority of subjects enrolled in the DPP (88\%) entered the DPPOS, an epidemiologic follow-up study, at the end of the randomised phase of the trial [69]. Treatment with placebo was discontinued while treatment with metformin $850 \mathrm{mg}$ twice daily was continued unless changes to medication were required for managing diabetes or for other reasons. All subjects received instruction on 
following a healthy lifestyle based on aspects of the intensive lifestyle intervention. The study population are being followed-up as an observational cohort for composite microvascular and macrovascular endpoints in addition to incident diabetes [84].

Ten-year effects on diabetes incidence and weight loss were evaluated in 2766 subjects (910 from the original intensive lifestyle intervention group, 924 from the original metformin group, and 932 from the original placebo group). Mean body weight at the end of the randomised phase of the DPP was $90.6 \mathrm{~kg}$ for the intensive lifestyle intervention, $92.0 \mathrm{~kg}$ for metformin, and $93.4 \mathrm{~kg}$ for placebo, consistent with the greater weight loss with the intensive lifestyle intervention versus other groups during the initial phase of the study. During the DPPOS, the original intensive lifestyle intervention group regained approximately $1 \mathrm{~kg}$, while weight loss in the original metformin and placebo groups was similar for the beginning and end of the observational phase in the DPPOS. Thus, mean weight was similar for patients originally randomised to the intensive lifestyle intervention or metformin after 10 years of randomised and observational follow-up.

Diabetes incidence rates (per 100 person-years) during the DPPOS, according to treatment assignment in the DPP, were 4.9 (95\% CI 4.2-5.7) for metformin, 5.9 (95\% CI 5.1-6.8) for the intensive lifestyle intervention, and 5.6 (95\% CI 4.8-6.5) for placebo. The apparent benefit for metformin relative to lifestyle intervention during the DPPOS phase was due to reduced diabetes incidence rates in the metformin (and placebo) group compared with an increasing rate in the intensive lifestyle group. Further analysis has implicated the weight gain in the former intensive lifestyle intervention group as a key factor in the increased diabetes incidence observed in these subjects in the DPPOS, while 'exhaustion of susceptibles', i.e. patients with genetic susceptibility to diabetes in the metformin and placebo groups had already developed diabetes by the time the DPPOS commenced, was likely due to the reduced diabetes incidence in the other groups [85]. Surprisingly, it appeared that the provision of a lifestyle intervention for the metformin and placebo groups was not associated with the declining diabetes incidence in these groups.

The diabetes incidence rate remained lowest for the intensive lifestyle intervention for the DPP and DPPOS phases combined, with a reduction in diabetes incidence of $34 \%$ (95\% CI 24-42) for the original intensive lifestyle intervention group and $18 \%$ (95\% CI 7-28) for the original metformin group. The risk of developing diabetes was lowest for patients who had reverted from IGT to normal glucose regulation, irrespective of original treatment assignment [86]. Increased $\beta$-cell function and insulin resistance were significantly associated with reversion to normal glucose tolerance and inversely associated with the risk of developing diabetes. An association between the use of antidepressants and increased risk of diabetes (see below) persisted into the DPPOS phase [87].

Improvements in lipid parameters (low-density lipoprotein [LDL]-cholesterol, triglycerides and high-density lipoprotein [HDL]-cholesterol) and blood pressure occurred similarly between the original treatment groups during the 10-year follow-up period; however, there was a lower rate of use of pharmacologic lipid-modifying and antihypertensive therapy in the original intensive lifestyle intervention group, relative to other groups [88]. During the DPP, gastrointestinal side effects were more common on metformin relative to placebo (average of 28 vs. $16 \%$ for the first 4 years; $p<0.01$ ), as would be expected. The rate of these adverse events declined over time in the original metformin group so that the incidence was similar to that observed in the original placebo group by the end of the DPPOS [89]. No unexpected adverse events were encountered. There were three cases of anaemia presenting as serious adverse events (two on metformin, one on placebo) and no cases of lactic acidosis or hypoglycaemia presenting as a serious AE during nearly 18,000 subjectyears of follow-up.

\subsubsection{Further Analyses from the DPP Relating to Diabetes Prevention}

Numerous other analyses from the DPP have been presented, with regard to the effects of interventions on the risk of developing type 2 diabetes. The main outcomes from a series of selected analyses are summarised below.

Weight loss accounted for $64 \%$ of the beneficial effect of metformin versus placebo on diabetes risk [90]. Adding fasting insulin, proinsulin, insulinogenic index and leisure activity to weight loss explained $81 \%$ of the protective effect, increasing to $99 \%$ with the addition of fasting glucose. Changes in body weight, insulin sensitivity, and insulin secretion independently predicted the risk of developing diabetes in the DPP irrespective of treatment allocation [91]. The reduced diabetes risk on intensive lifestyle intervention in the DPP was strongly associated with loss of visceral fat, but the effect of metformin was independent of changes in adiposity [92-94]. African American women lost less weight compared with other ethnicities in the intensive lifestyle intervention group of the DPP, although there was no difference between ethnicities for weight loss in the metformin group [95]. Gender did not strongly predict changes in diabetes risk during weight loss overall [96].

Adherence to metformin therapy was higher for older versus younger patients [97]. Adherence decreased in line 
with increasing numbers of potential barriers to adherence, and increased in line with the number of overlapping strategies used by patients to maintain good adherence. The most common reason for not taking metformin regularly was 'forgetting' $(22 \%)$.

Prior gestational diabetes mellitus (GDM) increased the risk of developing type 2 diabetes by $71 \%$, versus women without GDM [98]. Metformin and intensive lifestyle intervention were approximately equally effective in women with prior GDM (approximately $50 \%$ reduction in diabetes risk). Intensive lifestyle was more effective than metformin for women without prior GDM (49 vs. $14 \%$ reductions in diabetes risk, respectively).

Health-related quality of life (HRQoL) improved modestly in the intensive lifestyle intervention arm of the DPP, mainly associated with weight loss, with no significant change in other treatment arms [99]. However, some HRQoL measures were reduced further in patients who became diabetic while undertaking intensive lifestyle intervention relative to those who became diabetic while taking metformin [100]. It may be important to manage expectations of patients undertaking intensive lifestyle interventions, who may benefit from a delay in diabetes onset but remain at high long-term risk of diabetes.

Circulating adiponectin levels increased significantly on intensive lifestyle intervention but not on metformin or placebo; changes in this parameter were associated with significantly lower diabetes risk only in the intensive lifestyle intervention group [101]. The relationship between adiponectin and diabetes risk in the intensive lifestyle intervention group was attenuated by adjustment for weight but remained significant.

The severity of depression was similar among the randomised treatment groups in the DPP [102]. Continuous use of antidepressants predicted a higher risk of diabetes in the intensive lifestyle intervention and placebo groups but not in the metformin group [97, 103].

Greater alcohol consumption was associated with lower insulin secretion and a lower adjusted risk of diabetes for intensive lifestyle intervention and metformin but not for placebo [104].

\subsubsection{Effects of Metformin on Cardiometabolic Risk Factors in the DPP}

The incidence of hypertension (30\% of participants at baseline) increased on placebo and metformin, and decreased with intensive lifestyle intervention [105]. Improvements in triglycerides occurred in all groups but were larger with intensive lifestyle intervention. Intensive lifestyle intervention increased mean HDL-cholesterol and decreased the incidence of the atherogenic LDL phenotype B. Total and LDL-cholesterol were similar between groups. Fewer subjects on intensive lifestyle intervention required pharmacologic treatment for cardiovascular risk factors versus placebo or metformin at 3 years. The metabolic syndrome was present in $53 \%$ of DPP participants at baseline; the incidence versus placebo over 3 years was reduced by $41 \%$ in the lifestyle group $(p<0.001)$ and by $17 \%$ in the metformin group $(p=0.03)[106]$.

Alterations in cardiovascular risk factors tended to parallel changes in glycaemic status, with little difference between treatment groups in cardiovascular risk factor status for subjects who progressed to type 2 diabetes [107]. Cardiovascular risk factor status was generally most favourable for the intensive lifestyle intervention arm.

Changes in urinary albumin:creatinine ratio varied little between treatments and exerted little effect on the risk of diabetes [108, 109]. Modest, but significant, improvements in serum alanine aminotransferase (a marker of hepatic function) and C-reactive protein (a marker of systemic inflammation) were mediated by weight loss $[110,111]$.

\subsubsection{Genetic Markers of Diabetes Risk or Cardiometabolic Outcomes in the DPP}

A high genetic risk score (GRS) based on deleterious alleles at 32 lipid-associated single-nucleotide polymorphisms (SNPs) predicted adverse lipid changes only in the intensive lifestyle intervention arm of the DPP [112]. Higher values of a GRS based on 34 loci associated with type 2 diabetes predicted an increased risk of developing type 2 diabetes in the DPP overall but without influence on the effect of individual treatments [113].

Key studies of individual mutations that influenced the risk of diabetes in the DPP are summarised in Table 4. Notably, the response to metformin in the DPP was associated, with varying extents, with variations in the genes for transporters of metformin and components of AMP kinase, with individual mutations increasing or decreasing the risk of diabetes [114]. Of 16 SNPs known to be associated with obesity, only one was significantly associated with metformin for long-term weight loss (NEGRI rs2815752); other SNPs were usually associated with shortor long-term weight loss with intensive lifestyle intervention, or irrespective of treatment [115]. Protective effects of polymorphisms in the WFS1 gene that are associated with improved $\beta$-cell function may be amplified by intensive lifestyle intervention [116]. Subjects with the diabetes riskconferring TT genotype at rs7903146 in the TCF7L2 gene (associated with diminished $\beta$-cell function) were more likely to progress to diabetes than subjects with the AA genotype at this location [117]; however, the interaction between genotype and treatment allocation did not achieve statistical significance. 
Table 4 Overview of associations of genetic variants with diabetes risk in the Diabetes Prevention Program

\begin{tabular}{|c|c|c|}
\hline Known association of genes with glucose regulation or effects of treatments & Specific genes or variants & References \\
\hline \multicolumn{3}{|l|}{ Mutations that influenced diabetes risk in the DPP } \\
\hline Genes for transporters of metformin & $S L C 47 A 1, L C 22 A 1$ & [114] \\
\hline AMP kinase or AMP kinase subunits & STK11, PRKAA1, PRKAA2, PRKAG2 & [114] \\
\hline Genes associated with weight loss & NEGR1 rs2815752 & {$[115]$} \\
\hline Polymorphisms associated with improved $\beta$-cell function & WFS1 & [116] \\
\hline Known diabetes risk allele & TT genotype at rs7903146 in the TCF7L2 gene $^{\mathrm{a}}$ & {$[117]$} \\
\hline \multicolumn{3}{|l|}{ Mutations that did not influence diabetes risk in the DPP } \\
\hline Genes influencing glucose regulation: & & [118] \\
\hline Fasting glucose & MTNR1B, G6PC2, GCKR & \\
\hline Impaired $\beta$-cell function & MTNR1B & \\
\hline Increased insulinogenic index & G6PC2 & \\
\hline Ataxia-telangiectasia-mutated gene ${ }^{\mathrm{b}}$ & $\mathrm{C}$ allele at polymorphism rs11212617 & [119] \\
\hline
\end{tabular}

No effect on diabetes risk was observed for genetic variants previously reported to be associated with disturbed glucose regulation (fasting glucose, impaired $\beta$-cell function or insulinogenic index) [118], or for the $\mathrm{C}$ allele at the rs11212617 polymorphism in the ataxia-telangiectasiamutated gene, which has been previously associated with a larger clinical response to metformin [119].

\subsection{The Indian DPP (IDPP)}

The IDDP differed from the DPP in that an intensive lifestyle intervention and metformin were evaluated separately and in combination, each in comparison with a control group given standard healthcare advice [65]. For this trial, subjects involved in physical labour or regular exercise, or who needed to walk or cycle for more than $30 \mathrm{~min}$ each day, were exempt from additional exercise targets; other subjects in this group were advised to walk briskly for at least 30 $\mathrm{min} /$ day. Metformin was initially given at a dose of $250 \mathrm{mg}$, titrated to $250 \mathrm{mg}$ twice daily after 2 weeks, according to tolerability. The dose was lower than that used in the DPP to account for the smaller average body size of South Asian versus American subjects.

Similar reductions in the risk of diabetes were observed in active treatment groups, with no sign of synergy between the lifestyle intervention and metformin (Table 3). Numbers needed to treat ranged between 6.4 and 6.9 to prevent one case of incident diabetes. There were no significant changes in body weight at 3 years in any group. The proportions of patients with elevated LDL-cholesterol decreased in all active treatment groups but not in the control group, while the prevalence of hypertension increased significantly in all groups, irrespective of treatment [120].
A cutoff value for $\mathrm{HbA}_{1 \mathrm{c}}$ of $43 \mathrm{mmol} / \mathrm{mol}(6.05 \%)$ predicted new-onset diabetes with $67 \%$ sensitivity and $60 \%$ specificity in the IDDP [121]. As in the DPP, subjects with more severe insulin resistance or $\beta$-cell dysfunction at baseline were more likely to develop diabetes, and diabetes prevention was associated with improvements in these parameters [122]. However, although insulin resistance (HOMA-IR) increased in line with the number of criteria for the metabolic syndrome, the presence or absence of metabolic syndrome criteria per se did not influence the risk of developing diabetes (HR 1.02; $95 \%$ CI 0.78-1.35; $p=0.88)$ [123].

\subsection{The Low-Dose Combination Therapy with Rosiglitazone and Metformin to Prevent Type 2 Diabetes Mellitus (CANOE) Study}

The low-dose combination therapy with rosiglitazone and metformin to prevent type 2 diabetes mellitus study (CANOE) sought to avoid the common adverse events associated with rosiglitazone (oedema with increased risk of incident heart failure) and metformin (gastrointestinal side effects, principally diarrhoea) by using rosiglitazone and metformin in a low-dose combination in a 4-year, randomised, placebo-controlled study in subjects with IGT [64]. The reduction in the risk of new-onset type 2 diabetes in the CANOE study was at least comparable to the risk reductions observed in the other studies using metformin, and was also comparable to the risk reductions observed with intensive lifestyle interventions or rosiglitazone in other studies (Table 3). However, the combination treatment did not alter the rate of progression of decreases in insulin sensitivity and $\beta$-cell function [124]. 
Current prescribing restrictions relating to safety concerns with thiazolidinediones [125] potentially limit any future role for thiazolidinedione-based combinations in diabetes prevention. However, the CANOE study established an important principle in that effective diabetes prevention can be achieved using low-dose combinations of drugs that minimise the potential for side effects. Another study found that targeted combinations of metformin with pioglitazone or exenatide (based on results from oral glucose tolerance tests) induced more marked improvements in indices of glycaemic function than lifestyle intervention in 105 subjects with IGT and/or IFG, although diabetes outcomes were not measured here [126].

\section{Other Clinical Evidence for Diabetes Prevention with Metformin}

\subsection{Systematic Reviews and Meta-Analyses on Diabetes Prevention}

A meta-analysis of three diabetes prevention studies [19, $65,66]$ presented data in two ways: (a) as presented by the original authors; and (b) including all subjects enrolled in each study as a true intention-to-treat analysis with a 'worst-case' scenario, where subjects lost to follow-up on metformin or control treatment were assumed to have progressed/not progressed to diabetes, respectively [127]. Metformin significantly prevented diabetes when analysed in either of these ways, and also when only considering placebo-controlled data or the use of low doses of metformin in Asian subjects (Fig. 4). A further systematic review, which did not attempt a meta-analysis, concluded that while there is substantial evidence that lifestyle or pharmacologic interventions effectively delay or prevent diabetes, there was insufficient evidence to compare their effectiveness [128].

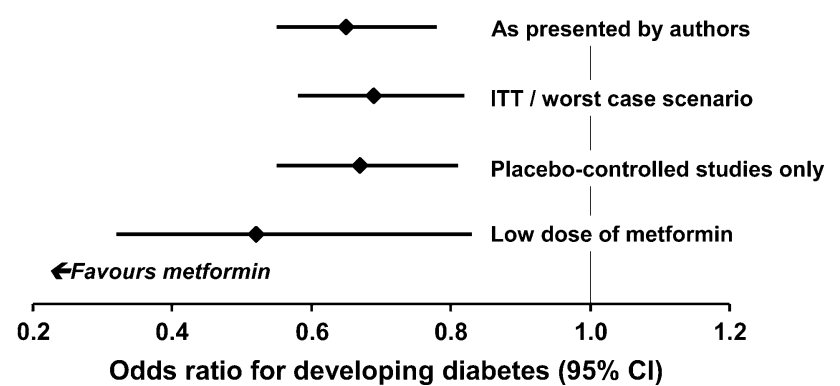

Fig. 4 Main results of a meta-analysis of diabetes prevention studies with metformin. See text for a description of the ITT/worst-case scenario. Adapted from data presented by Lily and Godwin [127]. ITT intention-to-treat analysis

\subsection{Studies in Insulin-Resistant Adult Populations}

A 12-month observational study in 366 overweight/obese subjects in Greece (all received a lifestyle intervention and 95 received metformin) demonstrated a reduced frequency of diabetes in the metformin-treated cohort (absolute risk difference $7 \% ; p=0.012$ ) [129]. Larger effects were observed in subjects with prediabetic dysglycaemia (absolute risk difference $18.5 \% ; p=0.01$ ) or the metabolic syndrome (absolute risk difference $12.9 \% ; p=0.04$ ) at baseline. The reduction in diabetes incidence was associated with reduced FPG, total cholesterol and LDL-cholesterol, and increased HDL-cholesterol.

Further studies, described below, did not include newonset diabetes in their endpoints but evaluated the effect of metformin on parameters relevant to diabetes prevention (primarily insulin resistance) in non-diabetic populations. The IDDP [53] and the studies by Wenying et al. [68] and Li et al. [66] did not demonstrate an additional effect of combining a lifestyle intervention with metformin, relative to that of metformin alone (see Table 3). A study in 32 subjects with IGT showed that exercise training, metformin, and exercise training with metformin all increased insulin sensitivity relative to a placebo control, with no significant difference between active treatment groups [130]. An observational study in Thailand showed that the proportion of subjects with IGT who reverted to normal glucose tolerance was similar for subjects receiving lifestyle intervention alone $(83 \%)$ or with metformin $(85 \%)$ [131]. A post hoc analysis of the 1-year, randomised Biguanides and the Prevention of the Risk of Obesity (BIGPRO1) study demonstrated significant improvements for metformin vs. placebo in FPG, systolic BP, and total and LDL-cholesterol in abdominally obese subjects with IGT or IFG [132]. Similar benefits of metformin were observed in subjects who met the inclusion criteria for the DPP in this analysis. Randomisation of 40 participants in the Botnia cohort in Sweden, who had IGT and a firstdegree relative with type 2 diabetes, resulted in improved glucose homeostasis that was sustained over 12 months [133]. In addition, little information is available on optimal dietary management for use alongside metformin: the RESIST (Researching Effective Strategies to Improve Insulin Sensitivity in Children and Teenagers) study is currently comparing two diets in obese, metformin-treated children and adolescents with IFG, IGT or elevated insulin resistance [134].

\subsection{Studies in Paediatric Patients}

Again, the studies described here did not include new-onset diabetes as an endpoint, and effects on clinical parameters relevant to diabetes prevention are described here. Table 5 
Table 5 Evaluations of metformin in paediatric, non-diabetic populations

\begin{tabular}{|c|c|c|c|c|}
\hline Location & $\begin{array}{l}\text { Main inclusion } \\
\text { criteria }\end{array}$ & $N$; duration & Treatments & Key findings \\
\hline $\begin{array}{c}\text { Australia } \\
{[135]}\end{array}$ & $\begin{array}{l}\text { Obesity (assumed } \\
\text { insulin resistance) }\end{array}$ & $28 ; 6$ months & $\begin{array}{l}\text { Placebo vs. metformin } \\
2000 \mathrm{mg} / \text { day }\end{array}$ & $\begin{array}{l}\text { Significantly better improvement for metformin vs. } \\
\text { placebo in anthropometric indices and fasting } \\
\text { insulin }\end{array}$ \\
\hline US [136] & $\begin{array}{l}\text { BMI }>30, \\
\quad \text { hyperinsulinaemia }\end{array}$ & $29 ; 6$ months & $\begin{array}{l}\text { Placebo vs. metformin } \\
1000 \mathrm{mg} / \text { day }\end{array}$ & $\begin{array}{l}\text { Significant improvement in insulin and glucose on } \\
\text { metformin }\end{array}$ \\
\hline US [137] & Hyperinsulinaemia & $24 ; 8$ week & $\begin{array}{l}\text { Placebo vs. metformin } \\
1700 \mathrm{mg} / \text { day }\end{array}$ & $\begin{array}{l}\text { Significant improvements in BMI, body fat, insulin } \\
\text { response on metformin }\end{array}$ \\
\hline UK [138] & IGT, IFG & $\begin{array}{l}151 ; \\
6 \text { months }\end{array}$ & $\begin{array}{l}\text { Placebo vs. metformin } \\
1500 \mathrm{mg} / \text { day }\end{array}$ & $\begin{array}{l}\text { Significant improvements in BMI, FPG and liver } \\
\text { function tests on metformin }\end{array}$ \\
\hline $\begin{array}{r}\text { Mexico } \\
{[139]}\end{array}$ & IGT & $52 ; 3$ months & $\begin{array}{l}\text { Placebo vs. metformin } \\
1700 \mathrm{mg} / \text { day, each plus lifestyle } \\
\text { advice }\end{array}$ & $\begin{array}{l}\text { Significant improvements on metformin in } \mathrm{HbA} 1 \mathrm{c} \text {, } \\
\text { HOMA-IR, resistin }\end{array}$ \\
\hline $\begin{array}{l}\text { China } \\
{[140]}\end{array}$ & IGT & $30 ; 3$ months & $\begin{array}{l}\text { Metformin } 1000 \mathrm{mg} / \text { day plus } \\
\text { lifestyle intervention (no control } \\
\text { group) }\end{array}$ & $\begin{array}{l}\text { Significant improvements in BMI, blood pressure, } \\
\text { IGT status, lipids, HOMA-IR }\end{array}$ \\
\hline $\begin{array}{c}\text { Australia } \\
\text { [141] }\end{array}$ & $\begin{array}{l}\text { Obesity, } \\
\text { hyperinsulinaemia }\end{array}$ & $\begin{array}{l}\text { Meta-analysis } \\
\quad \text { (four } \\
\text { studies) }\end{array}$ & $\begin{array}{l}\text { Placebo vs. metformin, } \\
\text { each } \pm \text { standard lifestyle advice }\end{array}$ & $\begin{array}{l}\text { Significant improvement with metformin in HOMA- } \\
\text { IR and fasting insulin }\end{array}$ \\
\hline
\end{tabular}

$B M I$ body mass index, $I G T$ impaired glucose tolerance, $I F G$ impaired fasting glucose, $F P G$ fasting plasma glucose, $H O M A-I R$ homeostatic model assessment-insulin resistance

summarises details of clinical evaluations of metformin in paediatric patients without diabetes at baseline [135-141]. A 6-month crossover study compared the effects of metformin $2000 \mathrm{mg} /$ day and placebo in 28 obese, insulin-resistant young adolescents (mean age 12.5 years) [135]. Metformin was associated with significant reductions versus placebo in mean weight (treatment difference $-4.35 \mathrm{~kg}$; $p=0.02$ ), BMI (treatment difference $-1.26 \mathrm{~kg} / \mathrm{m}^{2}$; $p=0.002$ ), waist (treatment difference $-2.8 \mathrm{~cm}$; $p=0.003$ ) and fasting plasma insulin (treatment difference $-2.2 \mu \mathrm{U} / \mathrm{L} ; p=0.011$ ). Significant improvements also occurred in the metformin group in subcutaneous abdominal fat measured using CT scanning. A second 6-month study randomised 29 obese hyperinsulinemic adolescents to placebo or metformin $1000 \mathrm{mg} /$ day [136]. Significant improvements were observed in the metformin group for BMI ( $p<0.02$ vs. placebo), while improvements from baseline in plasma insulin and FPG occurred during metformin treatment $(p<0.02)$ but not during treatment with placebo. Another study randomised 24 obese, hyperinsulinemic adolescents to receive placebo or metformin $1700 \mathrm{mg} /$ day for 8 weeks [137]. Metformin markedly reduced body weight (by 6.5 vs. $3.8 \%$ on placebo; $p<0.01$ ), and improved indices of body-fat content and insulin resistance versus placebo.

The Metformin in Obese Children and Adolescents trial in the UK randomised 151 obese children or adolescents to metformin or placebo for 6 months [138]. Significant improvements in the metformin group were observed for BMI (the primary endpoint) at 6 months, with a mean change of $-0.1 \mathrm{SD}(95 \% \mathrm{CI}-0.18$ to $-0.02 ; p=0.02)$, and at 3 months for FPG $(-0.16 \mathrm{mmol} / \mathrm{L} ; 95 \% \mathrm{CI}-0.31$ to $-0.00 ; p=0.047)$; alanine aminotransferase levels $(-19 \% ; 95 \%$ CI -5 to $-36 \% ; p=0.008)$ and adiponectin:leptin ratio $(32 \%$; $95 \%$ CI $4-67 ; p=0.02)$. Another randomised, placebo-controlled study in 52 glucose-intolerant paediatric subjects showed that 12 weeks of treatment with metformin $850 \mathrm{mg}$ twice daily significantly reduced levels of resistin (a hormone associated with insulin resistance), HOMA-IR and HbA1c [139]. An uncontrolled, observational study in children in China reported similar results in that the clinical features of the metabolic syndrome, HOMA-IR and adiponectin levels were improved in 20/30 subjects who completed 3 months of treatment with metformin and a lifestyle intervention [140]. Finally, a meta-analysis of four randomised studies of at least 2 months' duration in children or adolescents showed that treatment with metformin versus placebo decreased fasting insulin (mean change $-9.6 \mu \mathrm{U} / \mathrm{mL}$; $95 \%$ CI 6.3-13.0), HOMA insulin resistance (mean change -2.7 ; $95 \%$ CI 1.7-3.6) and BMI (mean change $-1.7 \mathrm{~kg} / \mathrm{m}^{2} ; 95 \%$ CI $1.1-2.3$ ) [141].

\subsection{Obesity/Insulin Resistance Arising as a Consequence of Antipsychotic Therapy}

Obesity and insulin resistance are recognised side effects of some antipsychotic drugs, and $37 \%$ of a large cohort of 783 adult psychiatric inpatients receiving this treatment were recently found to have prediabetic dysglycaemia 
[142]. A number of randomised, controlled trials have demonstrated benefits in terms of improved glycaemic regulation and weight loss associated with coadministration of metformin with antipsychotic gents [143-150]. In one 16-week, double-blind study in 39 children and adolescents who gained at least $10 \%$ of initial body weight within 1 year of starting treatment with an atypical antipsychotic agent, randomisation to metformin was associated with weight stabilisation, while patients receiving placebo continued to gain weight at a rate of $0.31 \mathrm{~kg} /$ week [150].

Meta-analyses found a weight benefit for metformin versus placebo of $5 \mathrm{~kg}$ [151], $3.2 \mathrm{~kg}$ [152] or $4.8 \%$ [153] of initial weight. One meta-analysis found a non-significant reduction in the risk of type 2 diabetes (relative risk 0.30; $p=0.13$ ), although the studies included were not designed as outcomes trials [151]. Three studies showed no benefit for metformin on body weight in this setting [154-156].

Table 6 Health economic analyses based on the Diabetes Prevention Program/Diabetes Prevention Program Outcome Study

\begin{tabular}{ll}
\hline Country & Purpose of the study \\
\hline US [81] & Lifetime cost-utility of DPP interventions \\
US [157] & $\begin{array}{c}\text { Costs of interventions within the randomised } \\
\text { phase of the DPP }\end{array}$
\end{tabular}

Summary of main findings

ILI and metformin delayed diabetes onset by 11 and 3 years, respectively, and increased life expectancy by 0.5 and 2 years, respectively, due to projected lower incidence of diabetic complications. Cost per QALY vs. placebo was \$1100 dollars (ILI) and $\$ 31,300$ (metformin) for health service perspective, and $\$ 8800$ dollars (ILI) and \$29,900 (metformin) for societal perspective. ILI dominated metformin

3-year cost per subject of metformin relative to placebo:

Health system perspective: \$2191 (metformin); \$2269 (ILI)

Societal perspective: \$2412 (metformin); \$3540 (ILI)

Costs inside the trial were lower for placebo vs. other interventions and costs outside the trial were highest for placebo

US [158] Within-trial cost effectiveness from health system and societal perspectives

Health system perspective: cost of preventing one case of diabetes vs. placebo- $\$ 15,655$ (ILI) and $\$ 31,338$ (metformin); costs per QALY-\$31,512 (ILI) and \$99,611 (metformin)

Societal perspective: cost of preventing one case of diabetes vs. placebo- $\$ 24,426$ (ILI) and $\$ 34,489$ (metformin); costs per QALY - \$51,582 (ILI) and \$99,171 (metformin)

US [159] Ten-year evaluation of the cost effectiveness of DPP interventions from the DPP and DPPOS

US [160] Cost effectiveness of DPP interventions

Australia, France, Germany, Switzerland, UK [161]

Australia [162]

Germany [163]
Markov modelling of long-term implications of DPP interventions

\section{Markov model of DPP interventions in Australia}

Cost effectiveness of 'real world' diabetes prevention according to DPP interventions
Total direct medical costs were greater for ILI $(\$ 29,164)$ than metformin $(\$ 27,915)$ or placebo $(\$ 28,236)$. Discounted ICER (health system perspective) was $\$ 10,037$ for ILI vs. placebo and $\$ 13,420$ for ILI vs. metformin. Metformin was cost saving vs. placebo

ILI reduced 30-year diabetes risk in high-risk subjects from 72 to $61 \%$ in an Archimedes model; metformin provided approximately one-third as much long-term benefit as immediate ILI

ILI and metformin were cost saving vs. placebo in all countries except the UK $(+€ 1021$ for ILI and $+€ 378$ for metformin at 2002 values). Improvements in life expectancy were 0.35 years for metformin and 0.90 years for ILI

Lifetime incremental direct costs/subject vs. control-\$1217 (metformin), and a savings of $\$ 289$ (ILI). Incremental cost per QALY was $\$ 10,142$ for metformin. Probability of willingness-topay at $\$ 50,000$ was $78 \%$ (metformin) and $100 \%$ (ILI)

Metformin and ILI would prevent 42 and 184 cases of diabetes, respectively, of a total number of 14,908 cases of diabetes in a population of 72,500 over 3 years. Costs for ILI were $€ 856,507$ (health system perspective) and $€ 4,961,340$ (society perspective); costs for metformin were $€ 797,539$ (health system perspective) and $€ 1,335,204$ (society perspective). ICERs per case prevented for ILI vs. no intervention were $€ 4664$ (health system perspective) and $€ 27,015$ (societal perspective); corresponding figures for metformin were not provided

DPP Diabetes Prevention Program, DPPOS Diabetes Prevention Program Outcomes Study, ICER incremental cost-effectiveness ratio, ILI intensive lifestyle intervention, $Q A L Y$ quality-adjusted life-year 
Table 7 Health economic evaluations of metformin in prediabetes in studies other than the Diabetes Prevention Program

\begin{tabular}{|c|c|c|}
\hline Country & Purpose of the study & Summary of main findings \\
\hline $\begin{array}{l}\text { India } \\
{[164]}\end{array}$ & Within-trial cost effectiveness in the IDDP & $\begin{array}{l}\text { Direct medical costs/subject of interventions: \$61 (control); \$225 (ILI); \$220 } \\
\text { (metformin); \$270 (ILI + metformin). Incremental cost vs. control of } \\
\text { preventing one case of diabetes: \$1092 (ILI); \$1095 (metformin); \$1359 } \\
\text { (ILI + metformin) }\end{array}$ \\
\hline $\begin{array}{l}\text { Australia } \\
{[165]}\end{array}$ & $\begin{array}{l}\text { Cost effectiveness of interventions for prediabetes } \\
\text { identified during opportunistic screening }\end{array}$ & $\begin{array}{l}\text { Cost/DALY was AUS } \$ 22,500 \text { for ILI and AUS } \$ 21,500 \text { for metformin vs. no } \\
\text { intervention Combining ILI and metformin was not cost effective }\end{array}$ \\
\hline $\begin{array}{c}\text { Australia } \\
\text { [154] }\end{array}$ & $\begin{array}{l}\text { Modelling of economic output of Australians aged } \\
45-64 \text { years for 1993-2003 }\end{array}$ & $\begin{array}{l}\text { Metformin and ILI both increased the total number of person-days in the } \\
\text { workforce ( } 2612 \text { and } 3038 \text { days, respectively) and both increased total } \\
\text { income (AUS } \$ 97,095,000 \text { and AUS } \$ 113,049,000 \text {, respectively, at } 2003 \\
\text { prices), by reducing the incidence of diabetes and associated health problems }\end{array}$ \\
\hline $\begin{array}{l}\text { Germany } \\
{[155]}\end{array}$ & $\begin{array}{l}\text { Cost effectiveness of intervening for screening- } \\
\text { detected prediabetes }\end{array}$ & $\begin{array}{l}\text { ICER/QALY vs. no screening for the general screened population was } € 563 \\
\text { for ILI and } € 325 \text { for metformin. Interventions were cost saving when ICER } \\
\text { was calculated for the group diagnosed with prediabetes }\end{array}$ \\
\hline $\begin{array}{r}\text { Canada } \\
{[156]}\end{array}$ & $\begin{array}{l}10 \text {-year health economics of interventions to } \\
\text { prevent diabetes in subjects with IGT }\end{array}$ & $\begin{array}{l}\text { Cases of diabetes prevented among } 1000 \text { subjects: } 117 \text { (ILI), } 52 \text { (metformin), } \\
74 \text { (acarbose). ILI was more effective but increased costs depending on } \\
\text { implementation; acarbose and metformin reduced costs by nearly } \\
\$ 1000 / \text { subject }\end{array}$ \\
\hline US [147] & $\begin{array}{l}10 \text {-year health economics of interventions in the } \\
\text { DPP and DPPOS }\end{array}$ & $\begin{array}{l}\text { Metformin was cost saving vs. placebo }(-\$ 159) \text { or intensive lifestyle } \\
\text { intervention }(-\$ 2852) \text {; ILI was cost saving vs. placebo }(-\$ 323) \text {. Discounted } \\
\text { ICERs (cost/QALY, health system perspective) were } \$ 10,037 \text { for ILI vs. } \\
\text { placebo and } \$ 13,420 \text { for ILI vs. metformin }\end{array}$ \\
\hline US [157] & Cost effectiveness of five screening tests & $\begin{array}{l}\text { Costs of tests (random plasma/capillary glucose after } 50 \text { or } 75 \text { g OGTT, or } \\
\mathrm{HbA}_{1 \mathrm{c}} \text { ) with subsequent ILI or metformin were } \$ 181,000-192,000 \text {, which } \\
\text { was lower than the cost of no screening }(\$ 206,000)\end{array}$ \\
\hline US [158] & Cost effectiveness of five screening tests & $\begin{array}{l}\text { Screening for diabetes and high-risk prediabetes should target patients at } \\
\text { higher risk, especially BMI }>35 \mathrm{~kg} / \mathrm{m}^{2} \text {, systolic blood pressure } \\
\geq 130 \mathrm{mmHg} \text {, or age }>55 \text { years }\end{array}$ \\
\hline
\end{tabular}

AUS\$ Australian dollars, IDDP Indian Diabetes Prevention Programme, ICER incremental cost-effectiveness ratio, ILI intensive lifestyle intervention, $D A L Y$ disability-adjusted life-year, $Q A L Y$ quality-adjusted life-year, DPP Diabetes Prevention Program, DPPOS Diabetes Prevention Program Outcomes Study, IGT impaired glucose tolerance, OGTT oral glucose tolerance test, BMI body mass index

\section{Health Economic Aspects of Diabetes Prevention with Metformin}

The use of metformin for diabetes prevention was cost effective in analyses based on the DPP, whether based on a within-trial analysis, from a societal perspective, or on Markov modelling studies that extrapolated the DPP findings to the health systems of other countries (Table 6) [81, 157-163]. A 10-year economic evaluation of interventions in the DPP and DPPOS showed that metformin was cost saving relative to placebo, with comparable quality-adjusted life-years (QALY) gained, while intensive lifestyle intervention resulted in a higher average number of QALY gained [159]. The incremental cost-effectiveness ratio (change in cost/change in QALY) was $\$ 10,037$ for lifestyle intervention versus placebo, and $\$ 13,420$ for lifestyle intervention versus metformin. Incremental cost-effectiveness ratios were generally substantially higher from a societal perspective.

Table 7 summarises health economic analyses from this and other studies [159, 164-170]. The IDDP also showed that diabetes prevention with metformin was cost effective, with costs of approximately $\$ 1000-\$ 1400$ for prevention of one case of diabetes with metformin, intensive lifestyle intervention, or both interventions in combination [164]. Metformin or intensive lifestyle intervention were also cost-effective strategies for prevention of diabetes in at-risk subjects identified opportunistically or by screening in Germany [167], the US [169, 170], Canada [168] or Australia (although metformin plus intensive lifestyle intervention was not cost effective here) [165]. A further study in Australia showed that intervention with metformin or intensive lifestyle intervention in prediabetes increased subjects' ability to work and increase their average income [166].

Intensive lifestyle interventions were usually more cost effective than metformin due to the greater reductions in diabetes incidence with intensive lifestyle intervention versus metformin in the DPP, and hence greater projected reductions in the incidence of complications of diabetes in studies with long time horizons. Several studies demonstrated that screening for prediabetes was cost effective, compared with no screening, when subjects identified as prediabetic would be treated subsequently with a lifestyle intervention or metformin. 
Table 8 Overview of management guidelines for diabetes prevention, with reference to the place of metformin

\begin{tabular}{|c|c|}
\hline Sponsor & Summary of key recommendations relating to metformin \\
\hline ADA (US, 2014) [4] & $\begin{array}{l}\text { Metformin to be considered in IGT, IFG, HbA1c of } 5.7-6.4 \% \text {, especially in BMI }>35 \mathrm{~kg} / \mathrm{m}^{2} \text {, age } \\
<60 \text { years or prior GDM }\end{array}$ \\
\hline ADS/ADEA (Australia, 2007) [171] & Consider pharmacologic management of prediabetes after a 6-month trial of lifestyle intervention \\
\hline ALAD (Latin America, 2011) [172] & $\begin{array}{l}\text { First step is lifestyle management; if not sufficient and/or in additional risk factors, pharmacological } \\
\text { treatment (e.g. metformin) is recommended }\end{array}$ \\
\hline CDA (Canada, 2013) [173] & $\begin{array}{l}\text { Implement intensive lifestyle intervention to prevent type } 2 \text { diabetes; metformin may reduce the risk of } \\
\text { type } 2 \text { diabetes in subjects with IGT }\end{array}$ \\
\hline ESC/EASD (Europe, 2013) [10] & $\begin{array}{l}\text { Strong emphasis on healthy lifestyle for diabetes prevention but no specific management } \\
\text { recommendations are provided }\end{array}$ \\
\hline European Expert Group (2013) [34] & $\begin{array}{l}\text { Strong emphasis on lifestyle intervention, use metformin or acarbose second-line (subject to tolerability) } \\
\text { in people with IGT, or orlistat second-line in obese subjects }\end{array}$ \\
\hline $\begin{array}{l}\text { Ministry of Health (Chile, 2010) } \\
\text { [174] }\end{array}$ & Use metformin if lifestyle change is insufficient or in patients with risk factors \\
\hline IDF (Global, 2006) [175] & $\begin{array}{l}\text { Use metformin } 250-850 \mathrm{mg} / \text { day where lifestyle intervention is insufficiently effective in reducing body } \\
\text { weight and improving glucose tolerance }\end{array}$ \\
\hline IMSS (Mexico, 2009) [176] & $\begin{array}{l}\text { In addition to lifestyle change, metformin or acarbose are recommended to decrease the risk of developing } \\
\text { diabetes }\end{array}$ \\
\hline $\begin{array}{l}\text { International expert group (2008) } \\
\text { [177] }\end{array}$ & $\begin{array}{l}\text { Priority given to lifestyle management over pharmacologic therapy for patients at increased risk of type } 2 \\
\text { diabetes or cardiovascular disease }\end{array}$ \\
\hline MEMS (Malaysia, 2009) [178] & $\begin{array}{l}\text { Metformin to be considered in patients with additional risk factors or if lifestyle change alone is not } \\
\text { sufficient }\end{array}$ \\
\hline MSC (Spain, 2008) [179] & In addition to lifestyle change, treatment with metformin, acarbose or pioglitazone is mentioned \\
\hline RVEM (Venezuela, 2012) [180] & $\begin{array}{l}\text { First step is lifestyle management; if not sufficient and/or in additional risk factors, pharmacological } \\
\text { treatment (e.g. metformin) is recommended }\end{array}$ \\
\hline SBD (Brazil, 2011) [181] & $\begin{array}{l}\text { In addition to lifestyle change, treatment with metformin (preferable) or, alternatively, acarbose or } \\
\text { pioglitazone is mentioned }\end{array}$ \\
\hline SPE (Peru, 2012) [182] & Alter lifestyle change, metformin is recommended as second-line treatment \\
\hline TEMD (Turkey, 2013) [183] & $\begin{array}{l}\text { After lifestyle change as first-line, treatment with metformin(preferable) or other oral antidiabetic drugs as } \\
\text { second-line is mentioned }\end{array}$ \\
\hline $\begin{array}{l}\text { World Health Organization (Global, } \\
\text { 2006) [184] }\end{array}$ & $\begin{array}{l}\text { Highlights results of the DPP (including with metformin and the DPS for diabetes prevention; the main } \\
\text { focus is on improved lifestyle }\end{array}$ \\
\hline
\end{tabular}

$A D A$ American Diabetes Association, $A D E A$ Australian Diabetes Educators Association, $A D S$ Australian Diabetes Society, $A L A D$ Asociación Latinoamericana de Diabetes, $B M I$ body mass index, $C D A$ Canadian Diabetes Association, Diabetes Prevention Program, Eastern Mediterranean region, DPP Diabetes Prevention Program, DPS Diabetes Prevention Study, ESC European Society of Cardiology, EASD European Association for the Study of Diabetes, GDM gestational diabetes mellitus, $I D F$ International Diabetes Federation, $I F G$ impaired fasting glucose, $I G T$ impaired glucose tolerance, IMSS Instituto Mexicano del Seguro Social, MSC Ministerio de Sanidad y Consumo (Spain), RVEM Revista Venezolana de Endocrinologia y Metabolismo, SBD Sociedade Braziliera de Diabetes, SPE Sociedad Peruana de Endocrinología, TEMD Türkiye Endokrinoloji ve Metabolizma Dernegi

\section{Metformin in Management Guidelines for Diabetes Prevention}

A number of guidelines have been written on the management of subjects with prediabetes (Table 8) $[4,10,34,171-$ 184]. Most place their primary focus on lifestyle intervention. Where pharmacologic therapy is considered as a second-line intervention, most guidelines, including major international guidelines from expert groups in the US, Europe, and the International Diabetes Federation favour the use of metformin. The recent (2015) Position Statement from the American Diabetes Association recommends that metformin has the strongest evidence base of pharmacological agents for diabetes prevention [4]. Such a recommendation is consistent with a study demonstrating that most prediabetic subjects in the US would meet American Diabetes Association criteria for consideration for treatment with metformin (Fig. 5) [8, 16]. It should be noted that these recommendations are made despite the lack of an indication for diabetes prevention with metformin in most countries, including the US and most of Europe.

\section{Discussion}

The evolving global diabetes pandemic heralds a future increase in the burden of complications of diabetes on patients, families and national healthcare systems. As most 


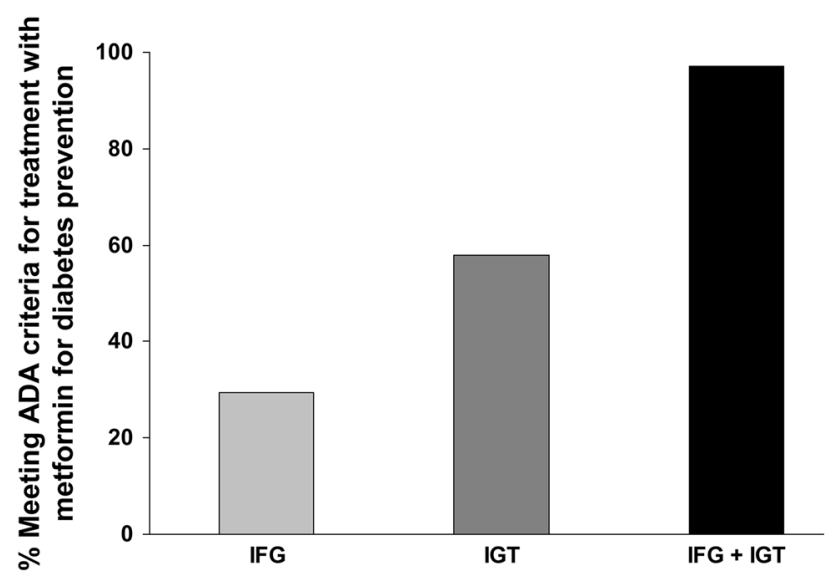

Fig. 5 Proportions of prediabetic subjects in the US meeting ADA criteria for treatment with metformin. Columns show estimated proportions meeting ADA criteria for use of metformin for IGT or IFG, pooled from data presented for three cohorts. Adapted from data presented by Rhee et al. [16]. ADA American Diabetes Association, $I G T$ impaired glucose tolerance, $I F G$ impaired fasting glucose

individuals with prediabetes will eventually go on to develop type 2 diabetes, the large number of people with prediabetes worldwide implies a reservoir of new type 2 diabetes cases to come. Optimising the management of prediabetes, with the aim of delaying diabetes onset for as long as possible, is therefore an urgent global clinical priority.

Lifestyle interventions have been shown to be effective in diabetes prevention in several large clinical trials, and are effective in subjects who comply with the intervention. Moreover, we know that the effectiveness of a lifestyle intervention increases in line with the number of lifestyle goals achieved. In the Diabetes Prevention Study (DPS), for example, no patient who achieved at least four of the five lifestyle goals (weight reduction, total fat intake, saturated fat intake, fibre intake, exercise) went on to develop diabetes during the period of follow-up [70]. Thus, subjects at risk of diabetes should be counselled on improving their lifestyle, as is the case for patients with a diagnosis of type 2 diabetes. However, weight loss arising from intensive lifestyle interventions is notoriously difficult to maintain over the long term, as shown by experience from the DPP, DPS and a number of other studies $[19,69,70,185,186]$. For this reason, current guidelines for the management of type 2 diabetes proposed jointly by the European Association for the Study of Diabetes and American Diabetes Association support the use of pharmacologic antidiabetic therapy (usually metformin) immediately after the diagnosis of diabetes for patients considered unlikely to benefit sufficiently from lifestyle intervention alone [187].
Clinical experience with metformin from large, randomised clinical trials supports the efficacy of metformin in diabetes prevention, especially among younger, heavier subjects. Importantly, these studies and five decades of clinical use in diabetes have established the relatively benign tolerability and acceptable safety profiles of metformin [60]. If experimental findings that are of potential relevance to the cardiovascular protection afforded by metformin are confirmed to be of clinical relevance, such as reduced levels of advanced glycation end-products or interference with cellular atherogenic processes (see Sect. 4.3), then such considerations would support the introduction of metformin as early in the progression of dysglycaemia as possible. Nevertheless, the gastrointestinal side effects of metformin can be troublesome and more than twice as many events occurred in the metformin versus placebo groups in the DPP (78 vs. 31 events/100 person-years, respectively) [19]. Adherence to metformin was only slightly lower than adherence to placebo in the DPP (72 vs. $77 \%$ took at least $80 \%$ of their prescribed medication, respectively [19]), but further research will be required to evaluate their impact of persistence with metformin-based therapy for diabetes prevention. The potential impact of vitamin $B_{12}$ depletion in prediabetic subjects will also require careful consideration.

The use of metformin in diabetes prevention is cost effective according to usual health economic criteria. In contrast, tolerability or safety issues may complicate the potential for the routine use, for diabetes prevention, of other agents shown to prevent or delay diabetes in the clinical trial setting, namely thiazolidinediones (oedema, increased cardiovascular risk, fractures), acarbose (high rate of discontinuation for gastrointestinal side effects), or basal insulin (hypoglycaemia) [188-190]. Newer, incretinbased therapies may hold potential for diabetes prevention but their evidence base is currently lacking [191]. These agents must overcome current safety concerns relating to pancreatitis and pancreatic cancer before they can be considered for routine use in patients with early dysglycaemia [192].

Metformin remains at the head of management algorithms for type 2 diabetes but the timing of its introduction within the course of dysglycaemia remains a matter for debate. The introduction of metformin could be merely masking the diagnosis of diabetes by reducing blood glucose, and evidence of improved long-term outcomes in metformin-treated people with prediabetes is required. This need is emphasised by the reluctance of regulators to consider conversion to diabetes as a genuine clinical outcome, with prevention or delay of its onset considered an unambiguous clinical benefit in its own right. However, a diagnosis of diabetes is itself life-changing, with a 
profound psychological impact on some patients (including 'grieving for lost health') and their families [193, 194]. A diagnosis of diabetes carries a social stigma, and people diagnosed with diabetes may face a lifetime of higher costs for, or reduced access to, health insurance, and limited access to certain professions [194, 195]. There remains a strong case for intervention to prevent conversion of prediabetes to clinical type 2 diabetes, which is recognised in current management guidelines.

\section{Conclusions}

A substantial proportion of subjects with prediabetes are likely to benefit from a combination of lifestyle intervention and pharmacologic intervention to prevent or delay the onset of type 2 diabetes. The current evidence base supports a role for metformin in diabetes prevention, combined with counselling, to achieve a healthier lifestyle.

\begin{abstract}
Acknowledgments Ulrike Hostalek and Steven Hildemann are employees of Merck KGaA, a pharmaceutical sponsor of several formulations of metformin. Steven Hildemann is Professor of Medicine at the University of Freiburg, Herzzentrum (Director, Professor Dr Christoph Bode), Freiburg, Germany. Mike Gwilt has previously received payment for medical communications services to Merck $\mathrm{KGaA}$ (no payment was received for contributing to the preparation of this review).
\end{abstract}

Open Access This article is distributed under the terms of the Creative Commons Attribution-NonCommercial 4.0 International License (http://creativecommons.org/licenses/by-nc/4.0/), which permits any noncommercial use, distribution, and reproduction in any medium, provided you give appropriate credit to the original author(s) and the source, provide a link to the Creative Commons license, and indicate if changes were made.

\section{References}

1. International Diabetes Federation. Complications of diabetes. Available at: http://www.idf.org/complications-diabetes. Accessed Jan 2015.

2. American Diabetes Association. Economic costs of diabetes in the U.S. in 2012. Diabetes Care. 2013;36:1033-46.

3. World Health Organization. Diabetes: the cost of diabetes. Available at: http://www.who.int/mediacentre/factsheets/fs236/ en/. Accessed Jan 2015.

4. American Diabetes Association. Standards of medical care in diabetes-2014. Diabetes Care. 2015;38(Suppl 1):S31-3.

5. Merlotti C, Morabito A, Pontiroli AE. Prevention of type 2 diabetes: a systematic review and meta-analysis of different intervention strategies. Diabetes Obes Metab. 2014;16:719-27.

6. DeFronzo RA, Bonnadonna RC, Ferrannini E. Pathogenesis of NIDDM. A balanced overview. Diabetes Care. 1992;15:318-68.

7. DeFronzo RA. Insulin resistance: a multifaceted syndrome responsible for NIDDM, obesity, hypertension, dyslipidaemia and atherosclerosis. Neth J Med. 1997;50:191-7.

8. Nathan DM, Davidson MB, DeFronzo RA, Heine RJ, Henry RR, Pratley R, et al. Impaired fasting glucose and impaired glucose tolerance: implications for care. Diabetes Care. 2007;30:753-9.
9. Buysschaert M, Bergman M. Definition of prediabetes. Med Clin North Am. 2011;95:289-97.

10. Rydén L, Grant PJ, Anker SD, Berne C, Cosentino F, Danchin $\mathrm{N}$, et al. ESC guidelines on diabetes, pre-diabetes, and cardiovascular diseases developed in collaboration with the EASD: the task force on diabetes, pre-diabetes, and cardiovascular diseases of the European Society of Cardiology (ESC) and developed in collaboration with the European Association for the Study of Diabetes (EASD). Eur Heart J. 2013;34:3035-87.

11. Genuth S, Alberti KG, Bennett P, Buse J, Defronzo R, Kahn R, et al. Follow-up report on the diagnosis of diabetes mellitus. Diabetes Care. 2003;26:3160-7.

12. World Health Organization: Definition, diagnosis and classification of diabetes mellitus and its complications. Report of a WHO Consultation. Part 1: diagnosis and classification of diabetes mellitus. Geneva: World Health Organization; 1999.

13. Mann DM, Carson AP, Shimbo D, Fonseca V, Fox CS, Muntner P. Impact of A1C screening criterion on the diagnosis of pre-diabetes among U.S. adults. Diabetes Care. 2010;33:2190-5.

14. Cohen RM, Haggerty S, Herman H. HbA1c for the diagnosis of diabetes and prediabetes: is it time for a mid-course correction? J Clin Endocrinol Metab. 2010;95:5203-6.

15. DeFronzo RA, Eldor R, Abdul-Ghani M. Pathophysiologic approach to therapy in patients with newly diagnosed type 2 diabetes. Diabetes Care. 2013;36(Suppl 2):S127-38.

16. Rhee MK, Herrick K, Ziemer DC, Vaccarino V, Weintraub WS, Narayan KM, et al. Many Americans have prediabetes and should be considered for metformin therapy. Diabetes Care. 2010;33:49-54.

17. Ziegler D, Rathmann W, Dickhaus T, Meisinger C, Mielck A. Prevalence of polyneuropathy in pre-diabetes and diabetes is associated with abdominal obesity and macroangiopathy: the MONICA/KORA Augsburg Surveys S2 and S3. Diabetes Care. 2008;31:464-9.

18. International Diabetes Federation Diabetes Atlas. 6th ed. Available at: http://www.idf.org/diabetesatlas/download-book. Accessed Jan 2015.

19. Diabetes Prevention Program Research Group. Reduction in the incidence of type 2 diabetes with lifestyle intervention or metformin. N Engl J Med. 2002;346:393-403.

20. Ramachandran A, Arun N, Shetty AS, Snehalatha C. Efficacy of primary prevention interventions when fasting and postglucose dysglycemia coexist: analysis of the Indian Diabetes Prevention Programmes (IDPP-1 and IDPP-2). Diabetes Care. 2010;33:2164-8.

21. Cheng YJ, Gregg EW, Geiss LS, Imperatore G, Williams DE, Zhang $\mathrm{X}$, et al. Association of A1c and fasting plasma glucose levels with diabetic retinopathy prevalence in the US population: implication for diabetes diagnostic thresholds. Diabetes Care. 2009;32:2027-77.

22. Nguyen TT, Wang JJ, Wong TY. Retinal vascular changes in prediabetes and pre- hypertension: new findings and their research and clinical implications. Diabetes Care. 2007;30:2708-15.

23. Barr EL, Zimmet PZ, Welborn TA, Jolley D, Magliano DJ, Dunstan DW, et al. Risk of cardiovascular and all-cause mortality in individuals with diabetes mellitus, impaired fasting glucose, and impaired glucose tolerance: the Australian Diabetes, Obesity, and Lifestyle Study (AusDiab). Circulation. 2007;116:151-7.

24. Coutinho M, Gerstein HC, Wang Y, Yusuf S. The relationship between glucose and incident cardiovascular events: a metaregression analysis of published data from 20 studies of 95,783 individuals followed for 12.4 years. Diabetes Care. 1999;22:233-40. 
25. DECODE Study Group. Glucose tolerance and cardiovascular mortality: comparison of fasting and 2-hour diagnostic criteria. Arch Intern Med. 2001;161:397-405.

26. Tyrberg M, Melander A, Lovestam-Adrian M, Lindblad U. Retinopathy in subjects with impaired fasting glucose: the NANSY-Eye baseline report. Diabetes Obes Metab. 2008;10:646-51.

27. Diabetes Prevention Program Research Group. The prevalence of retinopathy in impaired glucose tolerance and recent-onset diabetes in the Diabetes Prevention Program. Diabet Med. 2007;24:137-44.

28. DeFronzo RA, Abdul-Ghani M. Assessment and treatment of cardiovascular risk in prediabetes: impaired glucose tolerance and impaired fasting glucose. Am J Cardiol. 2011;108(3 Suppl):3B-24B.

29. Rydén L, Mellbin L. Glucose perturbations and cardiovascular risk: challenges and opportunities. Diabetes Vasc Dis Res. 2012;9:170-6.

30. Ferrannini E, Gastaldelli A, Iozzo P. Pathophysiology of prediabetes. Med Clin North Am. 2011;95:327-39.

31. Hopper I, Billah B, Skiba M, Krum H. Prevention of diabetes and reduction in major cardiovascular events in studies of subjects with prediabetes: meta-analysis of randomised controlled clinical trials. Eur J Cardiovasc Prev Rehabil. 2011;18:813-23.

32. Bingisser R, Cairns C, Christ M, Hausfater P, Lindahl B, Mair J, et al. Cardiac troponin: a critical review of the case for point-ofcare testing in the ED. Am J Emerg Med. 2012;30:1639-49.

33. Selvin E, Lazo M, Chen Y, Shen L, Rubin J, McEvoy JW, et al. Diabetes mellitus, prediabetes, and incidence of subclinical myocardial damage. Circulation. 2014;130:1374-82.

34. Paulweber B, Valensi P, Lindström J, Lalic NM, Greaves CJ, McKee M, et al. A European evidence-based guideline for the prevention of type 2 diabetes. Horm Metab Res. 2010;42(Suppl 1):S3-36.

35. Natali A, Ferrannini E. Effects of metformin and thiazolidinediones on suppression of hepatic glucose production and stimulation of glucose uptake in type 2 diabetes: a systematic review. Diabetologia. 2006;49:434-41.

36. Johnson AB, Webster JM, Sum CF, Argyraki M, Cooper BG, et al. The impact of metformin therapy on hepatic glucose production and skeletal muscle glycogen synthase activity in overweight type II diabetic patients. Metabolism. 1993;42:1217-22.

37. Wright AD, Cull CA, Macleod KM, Holman RR. Hypoglycemia in type 2 diabetic patients randomized to and maintained on monotherapy with diet, sulfonylurea, metformin, or insulin for 6 years from diagnosis: UKPDS73. J Diabetes Complicat. 2006;20:395-401.

38. Bailey CJ, Mynett KJ, Page T. Importance of the intestine as a site of metformin-stimulated glucose utilization. Br J Pharmacol. 1994;112:671-5.

39. Bailey CJ, Wilcock C, Day C. Effect of metformin on glucose metabolism in the splanchnic bed. $\mathrm{Br} \mathrm{J}$ Pharmacol. 1992;105:1009-13.

40. Wu T, Thazhath SS, Bound MJ, Jones KL, Horowitz M, Rayner CK. Mechanism of increase in plasma intact GLP-1 by metformin in type 2 diabetes: stimulation of GLP-1 secretion or reduction in plasma DPP-4 activity? Diabetes Res Clin Pract. 2014;106:e3-6.

41. Thondam SK, Cross A, Cuthbertson DJ, Wilding JP, Daousi C. Effects of chronic treatment with metformin on dipeptidyl peptidase- 4 activity, glucagon-like peptide 1 and ghrelin in obese patients with type 2 diabetes mellitus. Diabet Med. 2012;29:e205-10.
42. Cuthbertson J, Patterson S, O'Harte FP, Bell PM. Addition of metformin to exogenous glucagon-like peptide-1 results in increased serum glucagon-like peptide- 1 concentrations and greater glucose lowering in type 2 diabetes mellitus. Metabolism. 2011;60:52-6.

43. Liu Y, Hong T. Combination therapy of dipeptidyl peptidase-4 inhibitors and metformin in type 2 diabetes: rationale and evidence. Diabetes Obes Metab. 2014;16:111-7.

44. Napolitano A, Miller S, Nicholls AW, Baker D, Van Horn S, Thomas E, et al. Novel gut-based pharmacology of metformin in patients with type 2 diabetes mellitus. PLoS One. 2014;9:e100778.

45. Viollet B, Guigas B, Sanz Garcia N, Leclerc J, Foretz M, Andreelli F. Cellular and molecular mechanisms of metformin: an overview. Clin Sci (Lond). 2012;122:253-70.

46. Miller RA, Chu Q, Xie J, Foretz M, Viollet B, Birnbaum MJ. Biguanides suppress hepatic glucagon signalling by decreasing production of cyclic AMP. Nature. 2013;494:256-60.

47. Mannucci E, Ognibene A, Cremasco F, Bardini G, Mencucci A, Pierazzuoli E, et al. Effect of metformin on glucagon-like peptide 1 (GLP-1) and leptin levels in obese nondiabetic subjects. Diabetes Care. 2001;24:489-94.

48. Green BD, Irwin N, Duffy NA, Gault VA, O'harte FP, Flatt PR. Inhibition of dipeptidyl peptidase-IV activity by metformin enhances the antidiabetic effects of glucagon-like peptide-1. Eur J Pharmacol. 2006;547:192-9.

49. Wang DS, Jonker JW, Kato Y, Kusuhara H, Schinkel AH, Sugiyama Y. Involvement of organic cation transporter 1 in hepatic and intestinal distribution of metformin. J Pharmacol Exp Ther. 2002;302:510-5.

50. Becker ML, Visser LE, van Schaik RH, Hofman A, Uitterlinden $\mathrm{AG}$, Stricker BH. Interaction between polymorphisms in the OCT1 and MATE1 transporter and metformin response. Pharmacogenet Genomics. 2010;20:38-44.

51. UK Prospective Diabetes Study (UKPDS) Group. Effect of intensive blood-glucose control with metformin on complications in overweight patients with type 2 diabetes (UKPDS 34. Lancet. 1998;352:854-65.

52. Holman RR, Paul SK, Bethel MA, Matthews DR, Neil HA. 10-year follow-up of intensive glucose control in type 2 diabetes. N Engl J Med. 2008;359:1577-89.

53. Kooy A, de Jager J, Lehert P, Bets D, Wulffelé MG, Donker AJ, et al. Long-term effects of metformin on metabolism and microvascular and macrovascular disease in patients with type 2 diabetes mellitus. Arch Intern Med. 2009;169:616-25.

54. University of Oxford Diabetes Trials Unit. Glucose lowering in non-diabetic hyperglycaemia trial (ongoing). Available at: https://www.dtu.ox.ac.uk/GLINT/. Accessed Jan 2015.

55. de Jager J, Kooy A, Schalkwijk C, van der Kolk J, Lehert P, Bets $\mathrm{D}$, et al. Long-term effects of metformin on endothelial function in type 2 diabetes: a randomized controlled trial. J Intern Med. 2014;275:59-70.

56. Bailey CJ, Campbell IW, Chan JCN, Davidson JA, Howlett HCS, Ritz P, editors. Metformin, the gold standard: a scientific handbook. Chichester: Wiley, 2007. p. 135-152.

57. Scarpello JHB. Optimal dosing strategies for maximising the clinical response to metformin in type 2 diabetes. Br J Diabetes Vasc Dis. 2001;1:28-36.

58. Feher MD, Al-Mrayat M, Brake J, Leong KS. Tolerability of prolonged-release metformin (Glucophage) in individuals intolerant to standard metformin: results from four UK centres. Br J Diabetes Vasc Dis. 2007;7:225-8.

59. Cryer DR, Nicholas SP, Henry DH, Mills DJ, Stadel BV. Comparative outcomes study of metformin intervention versus conventional approach. The COSMIC Approach Study. Diabetes Care. 2005;28:539-43. 
60. Bailey CJ, Campbell IW, Chan JCN, Davidson JA, Howlett HCS, Ritz P, editors. Metformin, the gold standard: a scientific handbook. Chichester: Wiley; 2007. p. 173-192.

61. Singh AK, Kumar A, Karmakar D, Jha RK. Association of B12 deficiency and clinical neuropathy with metformin use in type 2 diabetes patients. J Postgrad Med. 2013;59:253-7.

62. de Jager J, Kooy A, Lehert P, Wulffelé MG, van der Kolk J, Bets $\mathrm{D}$, et al. Long-term treatment with metformin in patients with type 2 diabetes treated with insulin and risk of vitamin B12 deficiency: a randomised, placebo-controlled trial. BMJ. 2010;340:c2181.

63. Niafar M, Hai F, Porhomayon J, Nader ND. The role of metformin on vitamin B12 deficiency: a meta-analysis review. Intern Emerg Med. 2015;10:93-102.

64. Zinman B, Harris SB, Neuman J, Gerstein HC, Retnakaran RR, Raboud J, et al. Low-dose combination therapy with rosiglitazone and metformin to prevent type 2 diabetes mellitus (CANOE trial): a double-blind randomised controlled study. Lancet. 2010;376:103-11.

65. Ramachandran A, Snehalatha C, Mary S, Mukesh B, Bhaskar AD, Vijay V. The Indian Diabetes Prevention Programme shows that lifestyle modification and metformin prevent type 2 diabetes in Asian Indian subjects with impaired glucose tolerance (IDPP1). Diabetologia. 2006;49:289-97.

66. Li CL, Pan CY, Lu JM, Zhu Y, Wang JH, Deng XX, et al. Effect of metformin on patients with impaired glucose tolerance. Diabet Med. 1999;16:477-81.

67. Iqbal Hydrie MZ, Basit A, Shera AS, Hussain A. Effect of intervention in subjects with high risk of diabetes mellitus in Pakistan. J Nutr Metab. 2012;2012:867604.

68. Wenying Y, Lixiang L, Jinwu Q, Guangwei L, Zhiqing Y, Xiaoren $\mathrm{P}$. The preventive effect of acarbose and metformin on the IGT population from becoming diabetes mellitus: a 3-year multicentral prospective study. Chin J Endocrinol Metab. 2001;17:131-4.

69. Knowler WC, Fowler SE, Hamman RF, Christophi CA, Hoffman HJ, Brenneman AT, et al. 10-year follow-up of diabetes incidence and weight loss in the Diabetes Prevention Program Outcomes Study. Lancet. 2009;374:1677-86.

70. Tuomilehto J, Lindstrom J, Eriksson JG, Valle TT, Hämäläinen $\mathrm{H}$, Ilanne-Parikka P, et al. Prevention of type 2 diabetes mellitus by changes in lifestyle among subjects with impaired glucose tolerance. N Engl J Med. 2001;344:1343-50.

71. Pan XR, Li GW, Hu YH, Wang JX, Yang WY, An ZX, et al. Effects of diet and exercise in preventing NIDDM in people with impaired glucose tolerance: the Da Qing IGT and Diabetes Study. Diabetes Care. 1997;20:537-44.

72. Chiasson JL, Josse RG, Gomis R, Hanefeld M, Karasik A, Laakso M. Acarbose for prevention of type 2 diabetes mellitus: the STOP-NIDDM randomised trial. Lancet. 2002;359:2072-7.

73. Chiasson JL, Josse RG, Gomis R, Hanefeld M, Karasik A, Laakso M. Acarbose treatment and the risk of cardiovascular disease and hypertension in patients with impaired glucose tolerance: the STOP-NIDDM trial. JAMA. 2003;290:486-94.

74. Torgerson JS, Hauptman J, Boldrin MN, Sjöstrom L. XENical in the Prevention of Diabetes in Obese Subjects (XENDOS) Study. Diabetes Care. 2004;27:155-61.

75. Gerstein HC, Yusuf S, Bosch J, Pogue J, Sheridan P, Dinccag N, et al. Effect of rosiglitazone on the frequency of diabetes in patients with impaired glucose tolerance or impaired fasting glucose: a randomised controlled trial. Lancet. 2006;368:1096-105.

76. DREAM Trial Investigators. Effect of ramipril on the incidence of diabetes. N Engl J Med. 2006;355:1551-62.

77. Ramachandran A, Snehalatha C, Mary S, Selvam S, Kumar CK, Seeli AC, et al. Pioglitazone does not enhance the effectiveness of lifestyle modification in preventing conversion of impaired glucose tolerance to diabetes in Asian Indians: results of the Indian Diabetes Prevention Programme-2 (IDPP-2). Diabetologia. 2009;52:1019-26.

78. Carlsson LM, Peltonen M, Ahlin S, Anveden Å, Bouchard C, Carlsson B, et al. Bariatric surgery and prevention of type 2 diabetes in Swedish obese subjects. N Engl J Med. 2012;367:695-704.

79. Diabetes Prevention Program Research Group. The Diabetes Prevention Program. Design and methods for a clinical trial in the prevention of type 2 diabetes. Diabetes Care. 1999;22:623-34.

80. Fujimoto WY. Background and recruitment data for the U.S. Diabetes Prevention Program. Diabetes Care. 2000;23(Suppl 2):B11-3.

81. Herman WH, Hoerger TJ, Brandle M, Hicks K, Sorensen S, Zhang P, et al. The cost-effectiveness of lifestyle modification or metformin in preventing type 2 diabetes in adults with impaired glucose tolerance. Ann Intern Med. 2005;142:323-32.

82. Perreault L, Kahn SE, Christophi CA, Knowler WC, Hamman RF. Regression from pre-diabetes to normal glucose regulation in the diabetes prevention program. Diabetes Care. 2009;32:1583-8.

83. Diabetes Prevention Program Research Group. Effects of withdrawal from metformin on the development of diabetes in the Diabetes Prevention Program. Diabetes Care. 2003;26:977-80.

84. Diabetes Prevention Program Outcomes Study (DPPOS). Clinicaltrials.gov identifier NCT00038727. Available at: https:// clinicaltrials.gov/ct2/show/NCT00038727. Accessed Jan 2015.

85. Hamman RF, Horton E, Barrett-Connor E, Bray GA, Christophi $\mathrm{C}$, Crandall J, et al. Factors affecting the decline in incidence of diabetes in the Diabetes Prevention Program Outcome Study (DPPOS). Diabetes. 2015;64:989-98.

86. Perreault L, Pan Q, Mather KJ, Watson KE, Hamman RF, Kahn SE. Effect of regression from prediabetes to normal glucose regulation on long-term reduction in diabetes risk: results from the Diabetes Prevention Program Outcomes Study. Lancet. 2012;379:2243-51

87. Rubin RR, Ma Y, Peyrot M, Marrero DG, Price DW, BarrettConnor E, et al. Antidepressant medicine use and risk of developing diabetes during the diabetes prevention program and diabetes prevention program outcomes study. Diabetes Care. 2010;33:2549-51.

88. Orchard TJ, Temprosa M, Barrett-Connor E, Fowler SE, Goldberg RB, et al. Long-term effects of the Diabetes Prevention Program interventions on cardiovascular risk factors: a report from the DPP Outcomes Study. Diabet Med. 2013;30:46-55.

89. Diabetes Prevention Program Research Group. Long-term safety, tolerability, and weight loss associated with metformin in the Diabetes Prevention Program Outcomes Study. Diabetes Care. 2012;35:731-7.

90. Lachin JM, Christophi CA, Edelstein SL, Ehrmann DA, Hamman RF, Kahn SE, et al. Factors associated with diabetes onset during metformin versus placebo therapy in the diabetes prevention program. Diabetes. 2007;56:1153-9.

91. Kitabchi AE, Temprosa M, Knowler WC, Kahn SE, Fowler SE, Haffner SM, et al. Role of insulin secretion and sensitivity in the evolution of type 2 diabetes in the diabetes prevention program: effects of lifestyle intervention and metformin. Diabetes. 2005;54:2404-14.

92. Fujimoto WY, Jablonski KA, Bray GA, Kriska A, BarrettConnor E, Haffner S, et al. Body size and shape changes and the risk of diabetes in the diabetes prevention program. Diabetes. 2007;56:1680-5.

93. Diabetes Prevention Program Research Group. Relationship of body size and shape to the development of diabetes in the diabetes prevention program. Obesity (Silver Spring). 2006;14:2107-17. 
94. Bray GA, Jablonski KA, Fujimoto WY, Barrett-Connor E, Haffner S, Hanson RL, et al. Relation of central adiposity and body mass index to the development of diabetes in the Diabetes Prevention Program. Am J Clin Nutr. 2008;87:1212-8.

95. West DS, Elaine Prewitt T, Bursac Z, Felix HC. Weight loss of black, white, and Hispanic men and women in the Diabetes Prevention Program. Obesity (Silver Spring). 2008;16:1413-20.

96. Perreault L, Ma Y, Dagogo-Jack S, Horton E, Marrero D, Crandall J, et al. Sex differences in diabetes risk and the effect of intensive lifestyle modification in the Diabetes Prevention Program. Diabetes Care. 2008;31:1416-21.

97. Walker EA, Molitch M, Kramer MK, Kahn S, Ma Y, Edelstein $\mathrm{S}$, et al. Adherence to preventive medications: predictors and outcomes in the Diabetes Prevention Program. Diabetes Care. 2006;29:1997-2002.

98. Ratner RE, Christophi CA, Metzger BE, Dabelea D, Bennett $\mathrm{PH}, \mathrm{Pi}$-Sunyer $\mathrm{X}$, et al. Prevention of diabetes in women with a history of gestational diabetes: effects of metformin and lifestyle interventions. J Clin Endocrinol Metab. 2008;93:4774-9.

99. Florez H, Pan Q, Ackermann RT, Marrero DG, Barrett-Connor E, Delahanty L, et al. Impact of lifestyle intervention and metformin on health-related quality of life: the diabetes prevention program randomized trial. $\mathrm{J}$ Gen Intern Med. 2012;27:1594-601.

100. Marrero D, Pan Q, Barrett-Connor E, de Groot M, Zhang P, Percy $\mathrm{C}$, et al. Impact of diagnosis of diabetes on health-related quality of life among high risk individuals: the Diabetes Prevention Program outcomes study. Qual Life Res. 2014;23:75-88.

101. Mather KJ, Funahashi T, Matsuzawa Y, Edelstein S, Bray GA, Kahn SE, et al. Adiponectin, change in adiponectin, and progression to diabetes in the Diabetes Prevention Program. Diabetes. 2008;57:980-6.

102. Rubin RR, Knowler WC, Ma Y, Marrero DG, Edelstein SL, Walker EA, et al. Depression symptoms and antidepressant medicine use in Diabetes Prevention Program participants. Diabetes Care. 2005;28:830-7.

103. Rubin RR, Ma Y, Marrero DG, Peyrot M, Barrett-Connor EL, Kahn SE, et al. Elevated depression symptoms, antidepressant medicine use, and risk of developing diabetes during the diabetes prevention program. Diabetes Care. 2008;31:420-6.

104. Crandall JP, Polsky S, Howard AA, Perreault L, Bray GA, Barrett-Connor E, et al. Alcohol consumption and diabetes risk in the Diabetes Prevention Program. Am J Clin Nutr. 2009;90:595-601.

105. Ratner R, Goldberg R, Haffner S, Marcovina S, Orchard T, Fowler S, et al. Impact of intensive lifestyle and metformin therapy on cardiovascular disease risk factors in the diabetes prevention program. Diabetes Care. 2005;28:888-94.

106. Orchard TJ, Temprosa M, Goldberg R, Haffner S, Ratner R, Marcovina $\mathrm{S}$, et al. The effect of metformin and intensive lifestyle intervention on the metabolic syndrome: the Diabetes Prevention Program randomized trial. Ann Intern Med. 2005; 142:611-9.

107. Goldberg RB, Temprosa M, Haffner S, Orchard TJ, Ratner RE, Fowler SE, et al. Effect of progression from impaired glucose tolerance to diabetes on cardiovascular risk factors and its amelioration by lifestyle and metformin intervention: the Diabetes Prevention Program randomized trial by the Diabetes Prevention Program Research Group. Diabetes Care. 2009;32:726-32.

108. Diabetes Prevention Program Research Group. Changes in albumin excretion in the diabetes prevention program. Diabetes Care. 2009;32:720-5.

109. Friedman AN, Marrero D, Ma Y, Ackermann R, Narayan KM, Barrett-Connor E, et al. Value of urinary albumin-to-creatinine ratio as a predictor of type 2 diabetes in pre-diabetic individuals. Diabetes Care. 2008:31:2344-8.

110. Krakoff J, Clark JM, Crandall JP, Wilson C, Molitch ME, Brancati FL, et al. Effects of metformin and weight loss on serum alanine aminotransferase activity in the diabetes prevention program. Obesity (Silver Spring). 2010;18:1762-7.

111. Haffner S, Temprosa M, Crandall J, Fowler S, Goldberg R, Horton $\mathrm{E}$, et al. Intensive lifestyle intervention or metformin on inflammation and coagulation in participants with impaired glucose tolerance. Diabetes. 2005;54:1566-72.

112. Pollin TI, Isakova T, Jablonski KA, de Bakker PI, Taylor A, McAteer J, et al. Genetic modulation of lipid profiles following lifestyle modification or metformin treatment: the Diabetes Prevention Program. PLoS Genet. 2012;8:e1002895.

113. Hivert MF, Jablonski KA, Perreault L, Saxena R, McAteer JB, Franks PW, et al. Updated genetic score based on 34 confirmed type 2 diabetes Loci is associated with diabetes incidence and regression to normoglycemia in the diabetes prevention program. Diabetes. 2011;60:1340-8.

114. Jablonski KA, McAteer JB, de Bakker PI, Franks PW, Pollin TI, Hanson RL, et al. Common variants in 40 genes assessed for diabetes incidence and response to metformin and lifestyle intervention in the diabetes prevention program. Diabetes. 2010;59:2672-81.

115. Delahanty LM, Pan Q, Jablonski KA, Watson KE, McCaffery JM, Shuldiner A, et al. Genetic predictors of weight loss and weight regain after intensive lifestyle modification, metformin treatment, or standard care in the Diabetes Prevention Program. Diabetes Care. 2012;35:363-6.

116. Florez JC, Jablonski KA, McAteer J, Sandhu MS, Wareham NJ, Barroso I, et al. Testing of diabetes-associated WFS1 polymorphisms in the Diabetes Prevention Program. Diabetologia. 2008;51:451-7.

117. Florez JC, Jablonski KA, Bayley N, Pollin TI, de Bakker PI, Shuldiner AR, et al. TCF7L2 polymorphisms and progression to diabetes in the Diabetes Prevention Program. N Engl J Med. 2006;355:241-50.

118. Florez JC, Jablonski KA, McAteer JB, Franks PW, Mason CC, Mather K, et al. Effects of genetic variants previously associated with fasting glucose and insulin in the Diabetes Prevention Program. PLoS One. 2012;7:e44424.

119. Florez JC, Jablonski KA, Taylor A, Mather K, Horton E, White $\mathrm{NH}$, et al. The $\mathrm{C}$ allele of ATM rs11212617 does not associate with metformin response in the Diabetes Prevention Program. Diabetes Care. 2012;35:1864-7.

120. Snehalatha C, Mary S, Joshi VV, Ramachandran A. Beneficial effects of strategies for primary prevention of diabetes on cardiovascular risk factors: results of the Indian Diabetes Prevention Programme. Diab Vasc Dis Res. 2008;5:25-9.

121. Ramachandran A, Snehalatha C, Samith Shetty A, Nanditha A. Predictive value of $\mathrm{HbA1c}$ for incident diabetes among subjects with impaired glucose tolerance: analysis of the Indian Diabetes Prevention Programmes. Diabet Med. 2012;29:94-8.

122. Snehalatha C, Mary S, Selvam S, Sathish Kumar CK, Shetty SB, Nanditha A, et al. Changes in insulin secretion and insulin sensitivity in relation to the glycemic outcomes in subjects with impaired glucose tolerance in the Indian Diabetes Prevention Programme-1 (IDPP-1). Diabetes Care. 2009;32:1796-801.

123. Ramachandran A, Snehalatha C, Satyavani K, Sivasankari S, Vijay V. Metabolic syndrome does not increase the risk of conversion of impaired glucose tolerance to diabetes in Asian Indians: result of Indian Diabetes Prevention Programme. Diabetes Res Clin Pract. 2007;76:215-8.

124. Retnakaran R, Qi Y, Harris SB, Hanley AJ, Zinman B. Changes over time in glycemic control, insulin sensitivity, and beta-cell function in response to low-dose metformin and 
thiazolidinedione combination therapy in patients with impaired glucose tolerance. Diabetes Care. 2011;34:1601-4.

125. European Medicines Agency. European Medicines Agency recommends suspension of Avandia, Avandamet and Avaglim. Available at: http://www.ema.europa.eu/ema/index.jsp?curl= pages/news_and_events/news/2010/09/news_detail_001119.jsp. Accessed Jan 2015.

126. Armato J, DeFronzo RA, Abdul-Ghani M, Ruby R. Successful treatment of prediabetes in clinical practice: targeting insulin resistance and $\beta$-cell dysfunction. Endocr Pract. 2012;18:342-50.

127. Lily M, Godwin M. Treating prediabetes with metformin: systematic review and meta-analysis. Can Fam Physician. 2009;55:363-9.

128. Yuen A, Sugeng Y, Weiland TJ, Jelinek GA. Lifestyle and medication interventions for the prevention or delay of type 2 diabetes mellitus in prediabetes: a systematic review of randomised controlled trials. Aust N Z J Public Health. 2010;34:172-8.

129. Andreadis EA, Katsanou PM, Georgiopoulos DX, Tsourous GI, Yfanti GK, Gouveri ET, et al. The effect of metformin on the incidence of type 2 diabetes mellitus and cardiovascular disease risk factors in overweight and obese subjects-the Carmos study. Exp Clin Endocrinol Diabetes. 2009;117:175-80.

130. Malin SK, Gerber R, Chipkin SR, Braun B. Independent and combined effects of exercise training and metformin on insulin sensitivity in individuals with prediabetes. Diabetes Care. 2012;35:131-6.

131. Numbenjapon N, Nakavachara P, Santiprabhob J, Kiattisakthavee P, Wongarn R, Likitmaskul S. Successful strategy to improve glucose tolerance in Thai obese youth. J Med Assoc Thai. 2010;93(Suppl 6):S131-8.

132. Fontbonne A, Diouf I, Baccara-Dinet M, Eschwege E, Charles MA. Effects of 1-year treatment with metformin on metabolic and cardiovascular risk factors in non-diabetic upper-body obese subjects with mild glucose anomalies: a post-hoc analysis of the BIGPRO1 trial. Diabetes Metab. 2009;35:385-91.

133. Lehtovirta M, Forsén B, Gullström M, Häggblom M, Eriksson JG, Taskinen MR, et al. Metabolic effects of metformin in patients with impaired glucose tolerance. Diabet Med. 2001;18:578-83.

134. Garnett SP, Baur LA, Noakes M, Steinbeck K, Woodhead HJ, Burrell S, et al. Researching Effective Strategies to Improve Insulin Sensitivity in Children and Teenagers-RESIST. A randomised control trial investigating the effects of two different diets on insulin sensitivity in young people with insulin resistance and/or pre-diabetes. BMC Public Health. 2010;10:575.

135. Srinivasan S, Ambler GR, Baur LA, Garnett SP, Tepsa M, et al. Randomized, controlled trial of metformin for obesity and insulin resistance in children and adolescents: improvement in body composition and fasting insulin. J Clin Endocrinol Metab. 2006;91:2074-80.

136. Freemark M, Bursey D. The effects of metformin on body mass index and glucose tolerance in obese adolescents with fasting hyperinsulinemia and a family history of type 2 diabetes. Pediatrics. 2001;107:E55.

137. Kay JP, Alemzadeh R, Langley G, D’Angelo L, Smith P, Holshouser S. Beneficial effects of metformin in normoglycemic morbidly obese adolescents. Metabolism. 2001;50:1457-61.

138. Kendall D, Vail A, Amin R, Barrett T, Dimitri P, Ivison F, et al. Metformin in obese children and adolescents: the MOCA trial. J Clin Endocrinol Metab. 2013;98:322-9.

139. Gómez-Díaz RA, Talavera JO, Pool EC, Ortiz-Navarrete FV, Solórzano-Santos F, Mondragón-González R, et al. Metformin decreases plasma resistin concentrations in pediatric patients with impaired glucose tolerance: a placebo-controlled randomized clinical trial. Metabolism. 2012;61:1247-55.

140. Fu JF, Liang L, Zou CC, Hong F, Wang CL, Wang XM, et al. Prevalence of the metabolic syndrome in Zhejiang Chinese obese children and adolescents and the effect of metformin combined with lifestyle intervention. Int $\mathrm{J}$ Obes (Lond). 2007;31:15-22.

141. Quinn SM, Baur LA, Garnett SP, Cowell CT. Treatment of clinical insulin resistance in children: a systematic review. Obes Rev. 2010;11:722-30.

142. Manu P, Correll CU, van Winkel R, Wampers M, De Hert M. Prediabetes in patients treated with antipsychotic drugs. J Clin Psychiatry. 2012;73:460-6.

143. Wu RR, Jin H, Gao K, Twamley EW, Ou JJ, Shao P, et al. Metformin for treatment of antipsychotic-induced amenorrhea and weight gain in women with first-episode schizophrenia: a double-blind, randomized, placebo-controlled study. Am J Psychiatry. 2012;169:813-21.

144. Wang M, Tong JH, Zhu G, Liang GM, Yan HF, Wang XZ. Metformin for treatment of antipsychotic-induced weight gain: a randomized, placebo-controlled study. Schizophr Res. 2012;138:54-7.

145. Hoffmann VP, Case M, Jacobson JG. Assessment of treatment algorithms including amantadine, metformin, and zonisamide for the prevention of weight gain with olanzapine: a randomized controlled open-label study. J Clin Psychiatry. 2012;73:216-23.

146. Carrizo E, Fernández V, Connell L, Sandia I, Prieto D, Mogollón J, et al. Extended release metformin for metabolic control assistance during prolonged clozapine administration: a 14 week, double-blind, parallel group, placebo-controlled study. Schizophr Res. 2009;113:19-26.

147. Wu RR, Zhao JP, Jin H, Shao P, Fang MS, Guo XF, et al. Lifestyle intervention and metformin for treatment of antipsychotic-induced weight gain: a randomized controlled trial. JAMA. 2008;299:185-93.

148. Chen $\mathrm{CH}$, Chiu CC, Huang MC, Wu TH, Liu HC, Lu ML. Metformin for metabolic dysregulation in schizophrenic patients treated with olanzapine. Prog Neuropsychopharmacol Biol Psychiatry. 2008;32:925-31.

149. Klein DJ, Cottingham EM, Sorter M, Barton BA, Morrison JA. A randomized, double-blind, placebo-controlled trial of metformin treatment of weight gain associated with initiation of atypical antipsychotic therapy in children and adolescents. Am J Psychiatry. 2006;163:2072-9.

150. Baptista T, Rangel N, Fernández V, Carrizo E, El Fakih Y, Uzcátegui $\mathrm{E}$, et al. Metformin as an adjunctive treatment to control body weight and metabolic dysfunction during olanzapine administration: a multicentric, double-blind, placebo-controlled trial. Schizophr Res. 2007;93:99-108.

151. Praharaj SK, Jana AK, Goyal N, Sinha VK. Metformin for olanzapine-induced weight gain: a systematic review and metaanalysis. Br J Clin Pharmacol. 2011;71:377-82.

152. Ehret M, Goethe J, Lanosa M, Coleman CI. The effect of metformin on anthropometrics and insulin resistance in patients receiving atypical antipsychotic agents: a meta-analysis. J Clin Psychiatry. 2010;71:1286-92.

153. Björkhem-Bergman L, Asplund AB, Lindh JD. Metformin for weight reduction in non-diabetic patients on antipsychotic drugs: a systematic review and meta-analysis. J Psychopharmacol. 2011;25:299-305.

154. Arman S, Sadramely MR, Nadi M, Koleini N. A randomized, double-blind, placebo-controlled trial of metformin treatment for weight gain associated with initiation of risperidone in children and adolescents. Saudi Med J. 2008;29:1130-4.

155. Baptista T, Martínez J, Lacruz A, Rangel N, Beaulieu S, Serrano A, et al. Metformin for prevention of weight gain and insulin 
resistance with olanzapine: a double-blind placebo-controlled trial. Can J Psychiatry. 2006;51:192-6.

156. Baptista T, Sandia I, Lacruz A, Rangel N, de Mendoza S, Beaulieu S, et al. Insulin counter-regulatory factors, fibrinogen and $\mathrm{C}$-reactive protein during olanzapine administration: effects of the antidiabetic metformin. Int Clin Psychopharmacol. 2007;22:69-76.

157. Hernan WH, Brandle M, Zhang P, Williamson DF, Matulik MJ, Ratner RE, et al. Costs associated with the primary prevention of type 2 diabetes mellitus in the diabetes prevention program. Diabetes Care. 2003;26:36-47.

158. Diabetes Prevention Program Research Group. Within-trial costeffectiveness of lifestyle intervention or metformin for the primary prevention of type 2 diabetes. Diabetes Care. 2003;26:2518-23.

159. Diabetes Prevention Program Research Group. The 10-year cost-effectiveness of lifestyle intervention or metformin for diabetes prevention: an intent-to-treat analysis of the DPP/ DPPOS. Diabetes Care. 2012;35:723-30.

160. Eddy DM, Schlessinger L, Kahn R. Clinical outcomes and costeffectiveness of strategies for managing people at high risk for diabetes. Ann Intern Med. 2005;143:251-64.

161. Palmer AJ, Roze S, Valentine WJ, Spinas GA, Shaw JE, Zimmet PZ. Intensive lifestyle changes or metformin in patients with impaired glucose tolerance: modeling the long-term health economic implications of the diabetes prevention program in Australia, France, Germany, Switzerland, and the United Kingdom. Clin Ther. 2004;26:304-21.

162. Palmer AJ, Tucker DM. Cost and clinical implications of diabetes prevention in an Australian setting: a long-term modeling analysis. Prim Care Diabetes. 2012;6:109-21.

163. Icks A, Rathmann W, Haastert B, Gandjour A, Holle R, John J, et al. Clinical and cost-effectiveness of primary prevention of Type 2 diabetes in a 'real world' routine healthcare setting: model based on the KORA Survey 2000. Diabet Med. 2007;24:473-80.

164. Ramachandran A, Snehalatha C, Yamuna A, Mary S, Ping Z. Cost-effectiveness of the interventions in the primary prevention of diabetes among Asian Indians: within-trial results of the Indian Diabetes Prevention Programme (IDPP). Diabetes Care. 2007;30:2548-52.

165. Bertram MY, Lim SS, Barendregt JJ, Vos T. Assessing the costeffectiveness of drug and lifestyle intervention following opportunistic screening for pre-diabetes in primary care. Diabetologia. 2010;53:875-81.

166. Passey ME, Shrestha RN, Bertram MY, Schofield DJ, Vos T, Callander EJ, et al. The impact of diabetes prevention on labour force participation and income of older Australians: an economic study. BMC Public Health. 2012;12:16.

167. Schaufler TM, Wolff M. Cost effectiveness of preventive screening programmes for type 2 diabetes mellitus in Germany. Appl Health Econ Health Policy. 2010;8:191-202.

168. Caro JJ, Getsios D, Caro I, Klittich WS, O’Brien JA. Economic evaluation of therapeutic interventions to prevent type 2 diabetes in Canada. Diabet Med. 2004;21:1229-36.

169. Chatterjee R, Narayan KM, Lipscomb J, Phillips LS. Screening adults for pre-diabetes and diabetes may be cost-saving. Diabetes Care. 2010;33:1484-90.

170. Chatterjee R, Narayan KM, Lipscomb J, Jackson SL, Long Q, Zhu M, et al. Screening for diabetes and prediabetes should be cost-saving in patients at high risk. Diabetes Care. 2013;36:1981-7.

171. Twigg SM, Kamp MC, Davis TM, Neylon EK, Flack JR. Australian Diabetes Educators Association. Prediabetes: a position statement from the Australian Diabetes Society and Australian Diabetes Educators Association. Med J Aust. 2007;186:461-5.
172. Guzman JR. Documentos Selectos de Posición y Consenso de ALAD (Associatión Lationoamericano de diabetes) Ac Farmacéutica; 2011. ISBN: 9788560549559.

173. Committee Canadian Diabetes Association Clinical Practice Guidelines Expert. Reducing the risk of developing diabetes. Can J Diabetes. 2013;37:S16-9.

174. Ministerio de Salud. Gobierno de Chile. Guía Clínica Diabetes Mellitas Tipo 2. Serie Guías Cínicas Minsal 2010. Available at: http://web.minsal.cl/portal/url/item/72213ed52c3e23d1e040010 11f011398.pdf. Accessed Jan 2015.

175. Alberti KG, Zimmet P, Shaw J. International Diabetes Federation: a consensus on type 2 diabetes prevention. Diabet Med. 2007;24:451-63.

176. Instituto Mexicano del Seguro Social. Guía de Practica Clinica (GPC). Diagnóstico y Tratamiento de la Diabetes Mellitas tipo 2. Evidencias y Recomendaciones 2009 [extract]. Available at: http://www.imss.gob.mx/sites/all/statics/guiasclinicas/000GER_ DiabetesMellitus.pdf. Accessed Jan 2015.

177. Rosenzweig JL, Ferrannini E, Grundy SM, Haffner SM, Heine RJ, Horton ES, et al. Primary prevention of cardiovascular disease and type 2 diabetes in patients at metabolic risk: an endocrine society clinical practice guideline. J Clin Endocrinol Metab. 2008;93:3671-89.

178. Malaysian Endocrine Metabolic Society. Management of type 2 diabetes mellitus. 4th ed. 2009. Available at: http://www.moh. gov.my/attachments/3878.pdf. Accessed Jan 2015.

179. Ministrio de Sanidad y Consumo. Guía de Práctica Clínica sobre diabetes tipo 2. Guíasa Práctica Clínica en el SNS 2008. Available at: http://www.guiasalud.es/GPC/GPC_429_Diabetes_ 2_Osteba_compl.pdf. Accessed Jan 2015.

180. Guía Clínica Práctica en Diabetes Mellitus. Revista Venezolana de Endocrinologia y Metabolismo. 2012;10(Suppl 1):1-155.

181. Sociedade Brasiliera de Diabetes (SBD). Algoritmo para o tratamento do diabetes tipo 2. Atualização 2011. Posicionamento Oficial SBD n³, 2011.

182. Sociedad Peruana de Endocrinología. Consenso Peruano sobre Prevención y Tratamiento de Diabetes Mellitus Tipo 2, Síndrome Metabólico y Diabetes Gestacional. Congreso Internacional en Prediabetes y Síndrome Metabólico 2012. Available at: http://www.endocrinoperu.org/pdf/Consenso\%20Peruano\%20 sobre $\% 20$ Prevencion $\% 20 \mathrm{y} \% 20$ Tratamiento $\% 20 \mathrm{de} \% 20$ Diabetes $\%$ 20Mellitus $\% 202 \% 20$ Sindrome $\% 20$ Metabolico\%20y\%20Diabetes $\%$ 20Gestacional.pdf. Accessed Jan 2015.

183. Türkiye Endokrinoloji ve Metabolizma Dernegi. Díabetes Mellítus Ve Komplíkasyonlarinin TaniI, Tedaví Ve İzlem Kilavizu2013. Diabetes Mellitus Çalışma ve Eğitim Grubu 2013. Available at: http://www.turkendokrin.org/files/pdf/diabetes_ klvz2011_web.pdf. Accessed Jan 2015.

184. Eastern Mediterranean Regional office (WHO). Guidelines for the prevention, management and care of diabetes mellitus. EMRO Technical Publications Series 32. Available at: http:// www.emro.who.int/dsaf/dsa664.pdf. Accessed Jan 2015.

185. Lindström J, Ilanne-Parikka P, Peltonen M, Aunola S, Eriksson JG, Hemiö K, et al. Sustained reduction in the incidence of type 2 diabetes by lifestyle intervention: follow-up of the Finnish Diabetes Prevention Study. Lancet. 2006;368:1673-9.

186. Dombrowski SU, Knittle K, Avenell A, Araújo-Soares V, Sniehotta FF. Long term maintenance of weight loss with non-surgical interventions in obese adults: systematic review and meta-analyses of randomised controlled trials. BMJ. 2014;348:g2646.

187. Inzucchi SE, Bergenstal RM, Buse JB, Diamant M, Ferrannini E, Nauck M, et al. Management of hyperglycemia in type 2 diabetes: a patient-centered approach. Position statement of the American Diabetes Association (ADA) and the European Association for the Study of Diabetes (EASD). Diabetologia. 2012;55:1577-96. 
188. Kung J, Henry RR. Thiazolidinedione safety. Expert Opin Drug Saf. 2012;11:565-79.

189. National Diabetes education Initiative. Expert Commentary. Silvio E. Inzucchi, MD, on the ORIGIN insulin glargine trial results. Available at: http://www.ndei.org/ORIGIN-glarginestudy-silvioinzucchi-commentary.aspx. Accessed Jan 2015.

190. Arungarinathan G, McKay GA, Fisher M. Drugs for diabetes: part 4 acarbose. Br J Cardiol. 2011;18:78-81.

191. Neff KJ, le Roux CW. Incretins: new targets for the prevention of diabetes and obesity. Clin Lipidol. 2013;8:109-21.

192. Egan AG, Blind E, Dunder K, de Graeff PA, Hummer BT, Bourcier T, et al. Pancreatic safety of incretin-based drugs: FDA and EMA assessment. N Engl J Med. 2014;370:794-7.
193. Diabetes UK. Coping with your diagnosis: emotional impact and grief. Available at: http://www.diabetes.co.uk/emotions/copingwith-diabetes-diagnosis.html. Accessed May 2015.

194. Diabetes UK. Living with diabetes. Available at: http://www. diabetes.org.uk/guide-to-diabetes/living_with_diabetes. Accessed May 2015.

195. Schabert J, Browne JL, Mosely K, Speight J. Social stigma in diabetes: a framework to understand a growing problem for an increasing epidemic. Patient. 2013;6:1-10. 